\title{
Broadband Connectivity, Government Policies, and Open Innovation: The Crucial IT Infrastructure Contribution in Scotland
}

\author{
Sayed Abdul Majid Gilani ${ }^{1, *}$ and Alessio Faccia ${ }^{2}$ \\ 1 Edinburgh Business School, Heriot-Watt University, Edinburgh EH14 4AS, UK \\ 2 School of Business and Law, De Montfort University, Dubai 294345, United Arab Emirates; \\ alessio.faccia@dmu.ac.uk \\ * Correspondence: sg182@hw.ac.uk
}

check for updates

Citation: Majid Gilani, S.A.; Faccia, A. Broadband Connectivity, Government Policies, and Open Innovation: The Crucial IT Infrastructure Contribution in Scotland. J. Open Innov. Technol. Mark. Complex. 2022, 8, 1. https://doi.org/ 10.3390/joitmc 8010001

Received: 30 November 2021 Accepted: 24 December 2021 Published: 30 December 2021

Publisher's Note: MDPI stays neutral with regard to jurisdictional claims in published maps and institutional affiliations.

Copyright: (c) 2021 by the authors. Licensee MDPI, Basel, Switzerland. This article is an open access article distributed under the terms and conditions of the Creative Commons Attribution (CC BY) license (https:// creativecommons.org/licenses/by/ $4.0 /)$.

\begin{abstract}
Broadband connectivity is now essential to ensure a competitive advantage for any business. The analysis of Scotland's crucial IT infrastructure contribution supported the authors' thesis that the Government plays a decisive role in Open Innovation ecosystems. Indeed, IT infrastructures are a clear case of market failure where remote areas will never be served by adequate connectivity without public support. The main contribution is the demonstration that the benefits of public intervention are sometimes required and beneficial to correct market distortions and generate positive spillovers in terms of collaboration in Open Innovation ecosystems. Another relevant contribution is a comprehensive analysis of the consistency of the evolution of the public policies that supported the IT Infrastructure in Scotland. Therefore, pivotal is the study of this case study that can be easily generalised to many other contexts where the Government addressed market failures and, at the same time, contributed to generating collaborative environments.
\end{abstract}

Keywords: broadband connectivity; Scotland; open innovation; government policies

\section{Introduction}

The digital economy, consisting of the pervasive diffusion and intensive use of ICT (information and communication technologies) in the various sectors of the economy, is proceeding at an incredible pace both in industrialised and developing countries and also in Europe. The advancement objectives of the Information Society [1] continue to maintain a prominent place in community legislation and policy for economic development and social and territorial cohesion. The nodal point of the ICT paradigm of the last decade has been the infrastructural development [2]. It consists of the construction and use of broadband digital communication networks, which allow tendentially ubiquitous and high-speed access to the "network of networks" [3] of digital communication-universally known as the Internet [4]. The coverage of the territory with broadband networks acts as an infrastructural prerequisite and an essential enabling innovation for introducing a whole set of technologies, processes, and product and service innovations in the downstream sectors, configuring a process of technological diffusion cumulative and self-induced. Thanks to this Broadband infrastructure with higher data transmission capacity, the sectors and territories involved increase and de-materialise a growing part of the added value generated. It made them less dependent on the location and geographical accessibility of the production sites and consumption; consequently, they made possible a socio-economic repopulation of rural and marginal areas.

Therefore, there is a problem of public importance concerning the development of broadband networks, in the face of the emergence of a significant infrastructural digital gap connected to broadband (lack of service coverage), due to the lack of investments in large areas of the territory. Typically, these are the less urbanised and demographically 
marginal areas. This market failure [5] (presence of demand but lack of supply) is mainly because, in a market economy in which telecommunications companies (sometimes former public monopolists) [6] have now been privatised, the latter have public service obligations reduced (absent in the specific case of broadband) and-now deprived of state subsidies intended to finance the universal service - no longer find incentives to invest in high (and now very high) speed networks in areas with reduced population density.

\subsection{Broadband Connectivity}

Since the rise/mainstreaming of the Internet, the Internet and related Information and Communication Technologies (ICTs) have changed how we work and live $[7,8]$. The Internet is critical as a network of networks allowing the transfer and sharing of data/information, e.g., cloud computing, social media, e-commerce, and smartphones [9]. From a business perspective, this connectivity/new world of ICTs provides opportunities and threats (competitive advantage), as ICTs have transformed marketing, selling, supply chain, back-office processes (e.g., accounting and banking), collaborations, interfaces with Government, and so on $[10,11]$.

Underpinning much of this transformation is the 'pipeline' by which data are transferred via the Internet-broadband [12]. There must be two interrelated things to make all this work: (1) a pipeline offering connectivity; and (2) a sufficient bandwidth of connectivity that meets current/future data flow requirements [12]. An analogy could be-having a water pipe serving a village is good, but it also has to cope with the varying (and hopefully peak) demands on the flow of water at particular times of the day or as the village grows.

Broadband became widely available for public use in the United Kingdom (UK) from 2000 onwards [13]. The initial version of broadband was Asymmetric Digital Subscriber Line (ADSL) technology which was then followed by fibre optic, satellite, 3rd Generation (3G), 4th Generation (4G), and 5th Generation (5G) services [13]. The UK population has access to fixed-line and wireless versions of broadband, where fixed-line broadband can be adopted wirelessly through Wi-Fi (Wireless Fidelity) connectivity $[12,13]$. Broadband speeds are measured in megabits per second (Mbps) [12]. The average ADSL broadband speed in the UK is $11 \mathrm{Mbps}$. However, the UK's average speed of fibre optic broadband ranges between 35 and $60 \mathrm{Mbps}$, dependant on the Internet Service Provider (I.S.P.) [14]. The demand for faster and more reliable broadband is increasing (e.g., wider and faster broadband pipelines) with time due to the popularity of high data consuming services such as social media (e.g., high amounts of data are utilised through personal information being collected and used for advertising and marketing on sites like Facebook and Twitter), Netflix, YouTube (e.g., abnormally high level of data are used in streaming movies/videos online) and information management applications, e.g., accounting and transcribing applications [15].

As a result of all this-broadband connectivity for citizens/businesses is seen as key to being able to function/compete effectively in the 21st Century [16]. Additionally, it is argued that broadband access for all citizens and businesses should be a universal service obligation (USO) [17]. However, access to broadband (and sufficient bandwidth) is not universal: across countries. For example, in 2017, the entry-level broadband speeds in developing countries averaged $2 \mathrm{Mbps}$, with the equivalent figure for developed countries averaging $15 \mathrm{Mbps}$ [18]. Additionally, 85\% of households in developed countries and $51 \%$ of households in developing countries were identified as having broadband service, highlighting a substantial difference between developed and developing countries in terms of broadband access [18]. Therefore, broadband connectivity is now widely available in many developed countries (e.g., UK) though this is, perhaps, not universal [18].

In particular, typically, rural areas tend to be least connected to broadband in the UK and have lower broadband bandwidth than urban areas [19]. This aspect is not surprising as Internet Service Providers (I.S.P.s) in the UK as well as around the world tend to prioritise the delivery of updated infrastructure to areas with more significant populations (e.g., urban areas) to ensure a greater/maximised return (in the form of customer numbers), which is not applicable for most rural areas which have lower population numbers [20]. This situation 
between ISPs and rural communities has led to a digital divide (access to the Internet) between rural and urban areas in the UK, especially in Scotland [21,22]. Different authors identify that a digital divide is not simply based on access issues [22,23]. Van Deursen and Van Dijk [22] add that there have been two digital divides around the world where the first was Internet access issues in rural areas and the second is based on whether rural communities take up the Internet (e.g., is it worth their while? and do they have the skills to use it?). Hence, it can be implied that this notion of two digital divides also applies in the case of rural Scotland. Therefore, Van Deursen and Van Dijk [22] explain that overcoming the digital divide is not guaranteed even for areas with high broadband connections.

Van Deursen and Van Dijk [22] further elaborate on the notion of two digital divides by referring to costs and material access for maintaining Internet in more remote areas, e.g., are rural populations able to access the Internet on the same number of devices and at the exact cost as their urban counterparts? Another critical point Van Deursen and Van Dijk [22] is that rural communities may not feel that having low-level internet (e.g., poor speeds and intermittent connections) is worth their while as they may not carry out essential daily online tasks for them. For example, poor/limited Internet in a given area may be sufficient to conduct a Google search. Still, it may be insufficient in undertaking popular online tasks like banking, shopping, and communication. From the explanations on the digital divide provided by Van Deursen and Van Dijk [22], it can be concluded that in terms of broadband in rural areas, the first digital divide involves a lack of/no broadband connectivity in rural areas. The second digital divide consists of the inability of a rural population to fulfil their broadband needs despite a high level of broadband connectivity available in their area.

According to various authors, broadband adoption involves the initial take-up of broadband amongst communities (e.g., households or businesses). Therefore, for this paper, broadband adoption will be regarded as the initial take-up of broadband and broadband use will be identified as regular broadband use beyond initial broadband take-up [24-26]. However, for broadband adoption/use to be possible amongst communities, broadband connectivity is essential where for this paper, any level of access to broadband (e.g., Digital Subscriber Line (DSL), Asymmetric Digital Subscriber Line (ADSL); 3G/4G/5G) amongst communities will be regarded as broadband connectivity.

\subsection{Government Policies}

A collective consensus from different authors [27-29] identifies a Policy analysis as a method that offers a way of investigating how and why a given government implements specific policies and the by-product of this method of enacting policies. Therefore, the purpose of this article will be to critically review essential Scottish Government policy documents related to improving broadband connectivity and use from January 2006 to date. This analysis can therefore help determine the role of the Government in supporting broadband adoption/use in remote-rural Scotland. The critical policies, the related strategies, projects, and programmes will also be considered (for conciseness, in the rest of this article, the terms' policy' or 'policies' are used to denote one or more of policy, strategy, project, or programme unless the context is specific to one of these terms). Various authors (e.g., [30-32] identify the importance of Government activity via policy analysis on the growth and survival of Small to Medium Enterprises (SMEs), e.g., Government's role towards developing digital infrastructure, which may lead to improved conditions for small business growth (over $90 \%$ of United Kingdom (UK) businesses are SMEs [33]) or business' survival.

Additionally, Smith et al. [34] identify limited Scholarly evidence and knowledge on the influence of policy on the social exclusion for enterprises. Quinn et al. [35] propose further Research in understanding the role of the Government in supporting SMEs. Therefore, this policy analysis has been informed by the recommendations from these authors.

The geographic focus will be on Scotland in the UK; however, consideration will also be given to related EU and UK policies. The review will consider the aim of the policy, its key deliverables (intended and achieved as appropriate) and, given the objective of 
this work, the mention of issues relating to rurality, broadband adoption/use, and related drivers and barriers. The rest of this article is structured as follows: the policy review is chronologically based, divided into three time periods, 2006-2010, 2011-2016, and 2017 onwards (Sections 2-4).

From January 2006 to the present (approximately May 2021), policies, programs, and projects are reviewed as broadband was made available to over $99 \%$ of Scotland in December 2005, part of the SSI policy [36]. The following policy for improving broadband connectivity and broadband use in Scotland was the "Scotland's Digital Future: A Strategy for Scotland" policy initiated in 2011 [37], therefore leading to the first period of policy analysis being 2006-2010 and then the next period starting from 2011 onwards. The following primary policy in Scotland for improving digital connectivity, which included broadband, was the "Realising Scotland's full potential in a digital world: a digital strategy for Scotland" policy in 2017 [38,39]. This aspect informed the periods for policy analysis, including policies, programmes, and projects for broadband connectivity, adoption, and use in remote-rural Scotland as 2011-2016 and 2017 onwards. Therefore, policy analysis involved government documents (e.g., policies, programmes, and projects) from 2006-2010, 2011-2016, and 2017 onwards involving broadband connectivity, adoption, and daily broadband use in remote-rural Scotland. It has to be noted that older policies are now embedded in more recent websites, which will therefore lead to a disparity between the dates of the actual policy/programme/strategy and the source, e.g., the source of Superfast Broadband Digital Scotland [40] was adopted while discussing the Digital Scotland Superfast Broadband (DSSB) programme initiated in 2013.

The policy analysis will also be paired with relevant successful cases of Scottish companies that survived and strived thanks to the improved broadband infrastructure.

The selection for the three-time periods in the policy analysis is explained in Table 1.

Table 1. Policies periods and their rationale.

\begin{tabular}{cc}
\hline Time-Period for Policy Analysis & Reason Behind Time-Period \\
\hline $2006-2010$ & SSI policy led to broadband availability in over 98\% of Scotland from 2006 onwards. \\
$2011-2016$ & Scotland's Digital Future: A Strategy for Scotland policy created in 2011. \\
$2017-$ onwards & Realising Scotland's full potential in a digital world: a digital strategy for Scotland \\
policy created in 2017.
\end{tabular}

\subsection{Research Framework}

1.3.1. Possible Frameworks for Broadband Connectivity and Government Policies

Different frameworks/models (perspectives) have been adopted in past broadband-related studies to aid investigation towards understanding broadband adoption, e.g., Bass Diffusion Model [41], Diffusion of Innovations theory (DOI) [42], Technological Acceptance Model (T.A.M.) [43], and Technological Organisational Environmental (TOE) framework [44].

Each of these perspectives has aided understanding of broadband adoption in different ways. Based on the relationship between early adopters and late adopters in a given population group, Boucher [45], through the Bass Model, forecasted the level of broadband adoption in a future period for the same population group. The TAM allowed Li et al. [43] to investigate broadband adoption while considering social constructs, e.g., why does an owner-manager adopt/not adopt broadband?

The TOE framework gave Hoti [44] insight into broadband adoption by analysing technological, organisational, and environmental factors, e.g., business rivals encouraging broadband adoption is categorised under the ecological context.

Initial broadband adoption, as well as broadband use (initial post-adoption), were investigated by using the DOI theory [42] through its IDP (Innovation Decision Process) characteristic rather than solely focusing on initial broadband adoption/non-adoption [46].

Despite the insight gained on broadband adoption by including the frameworks/models of Bass, DOI, TAM 1/2/3, and TOE in past broadband adoption studies, none of these studies used the term 'drivers and barriers' for broadband adoption and broadband use. 
There was not a clear explanation of the role of the Government in the broadband adoption/use process related to communities. This identified paucity in existing literature led Gilani [47] to formulate the Broadband Adoption Framework (BAF), which investigated external and internal factors related to broadband adoption/use by businesses. However, the clarification on the role of the Government in supporting broadband adoption/use amongst communities was reasonably limited. Therefore, it is highlighted that there is an absence of a framework/model that addresses the role of the Government regarding broadband adoption/use by communities.

\subsubsection{Open Innovation Framework}

Among the various frameworks that can be considered, in Open innovation ecosystems [48], technologies and innovations are shared through knowledge co-creation. The decisive contribution provided by the public policies in spreading the broadband infrastructure is considered essential. The Government, in this case, plays an active role in the innovation and technological boost, overcoming market failures and providing support to the infrastructure, therefore reducing gaps among areas [49]. Moreover, this theoretical framework can be considered relevant to analysing broadband connectivity improvements' impact on the innovations introduced by businesses that helped them survive. The Government becomes an active partner in the open innovation process, favouring the conditions to provide equal and fair opportunities in Scotland.

\subsubsection{Research Questions}

To better identify and address under-researched areas of interest, main research questions have been designed for this Study. Therefore, the contribution of this article is easily paired with a successful answer to the following:

- RQ1: Is it possible to carry out a comprehensive Historical review on the EU/UK/Scottish Government documents on broadband adoption and broadband use? (addressed by Section 3)

- RQ2: Given the Historical Review, what are the primary outcome of a Policy analysis? (addressed by Section 4);

- RQ3: Is the contribution provided by the Government in Scotland valuable from an Open Innovation perspective? (addressed by Sections 5 and 6).

\section{Materials and Methods}

The analysis procedures of Historical review [50] and Policy analysis were adopted on EU/UK/Scottish Government documents on broadband (from January 2006 to May 2021).

The Historical review was chosen to ensure comprehensive analysis was performed correctly. It includes many sources to identify and appraise the specified topic. It also helps save time for readers potentially interested in different fields. A historical review is also based on intensely reliable sources that cannot be questioned.

Policy analysis is also implemented because it is essential to help define and outline a proposed policy's goals and identify similarities and differences in expected outcomes and estimated costs competing for alternative approaches. Textual analyses of policies and regulations issued during the considered timeframe were integrated by relevant literature previously identified by the historical review. The period breakdown further helped provide evidence and consistency along with better opportunities to focus on contextualised perspectives.

This approach was adopted to determine the level of EU/UK/Scottish Government activity towards improving broadband adoption, and broadband use in remote-rural Scotland since broadband with a minimum of $512 \mathrm{Kbs}$ was made available to $99 \%$ of Scotland in December 2005 [51].

This method informed the Research regarding broadband adoption/broadband use in remote-rural Scotland from a government and business perspective. Another contribution provided by this Research is the identification of three main periods. 
Indeed, the policy analysis/review was chronologically structured according to three primary shifts, 2006-2010, 2011-2016, and 2017 onwards (the policy analysis covered January 2006-May 2021).

This division of the policy analysis into three stages was based on the "Broadband for Scotland Rural and Remote Areas Supply-Side Intervention (SSI)" policy (99\% broadband availability in Scotland realised in December 2005), the "Scotland's Digital Future: A Strategy for Scotland" policy (initiated in 2011) and the "Realising Scotland's full potential in a digital world: a digital strategy for Scotland" policy (commenced in 2017).

Along with EU/UK/Scottish Government policies, the Policy analysis also reviewed government programmes and projects (e.g., DBBS, R100, and FFTP).

Below is the list of keywords searched in Google and Google Scholar to generate results related to Scottish/U.K. government policy on improving broadband access/use in rural Scotland.

Broadband policy; Broadband adoption; Broadband connectivity; Broadband take up; Government Policies; Internet policy; Open Innovation; Policy analysis; Rural development; Scotland; SMEs.

The analysis procedures of Historical review [52] (focuses on examining Research throughout a given period which in this case was January 2006-May 2021) and Policy analysis were adopted on EU/UK/Scottish Government documents on broadband (from January 2006 to May 2021).

Policy analysis is considered by different authors [27-29] as a method that investigates how and why a given government implements specific policies and the by-product of enacting policies.

The policy analysis/review was chronologically based, divided into three time periods, 2006-2010, 2011-2016, and 2017 onwards (the policy analysis covered January 2006-May 2021).

The search findings was then generated from the keywords inputted into Google, Google Scholar, and Scopus databases. Therefore, a systematic review approach was adopted for the literature review $[53,54]$. It should be noted that a Systematic review is explained as an overview of existing evidence appropriate and relevant to a drawn up/formulated research question. It adopts pre-specified and standardised/systematised methods to recognise and critically appraise relevant research and retrieve, describe/report, and analyse findings from studies in the review $[55,56]$.

The division of the policy analysis into three stages was based on the "Broadband for Scotland Rural and Remote Areas Supply-Side Intervention (SSI)" policy (99\% broadband availability in Scotland realised in December 2005), the "Scotland's Digital Future: A Strategy for Scotland" policy (initiated in 2011), and the "Realising Scotland's full potential in a digital world: a digital strategy for Scotland" policy (commenced in 2017). Along with EU/UK/Scottish Government policies, the Policy analysis also reviewed government programmes and projects (e.g., DSSB (Digital Scotland Superfast Broadband), R100 (Reaching 100) and FFTP (Fibre To The Premises)).

Bardach's Eightfold Pathway analysis is used (a method that consists of 8 steps developed by Eugene Bardach as a means of problem-solving related to policy analysis [57,58]). The methodology was then applied to the results and emerging themes from the policy analysis/review to aid the Research in establishing directions for future steps regarding the Government's role in improving broadband adoption/use in remote-rural Scotland.

\section{Historical Review and Policy Analysis}

\subsection{Policies and Strategies, Projects and Programs from 2006 to 2010}

The purpose of this section is to identify and discuss policies/strategies, projects and programmes focusing on broadband connectivity/take up/use from January 2006 to December 2010.

The fulfilment of the "Broadband for Scotland Rural and Remote Areas Supply-Side Intervention (SSI)" policy in December 2005 led to a minimum of affordable and essential broadband (512 kbps) offered to $99 \%$ of the Scottish population $[36,51,59]$. The realisation 
of this policy paved the way for other programmes and projects undertaken by BT and the EU/UK/Scottish Government. This section will analyse policies/strategies, projects, and programmes carried out or initiated in 2006-2010.

\subsubsection{6}

After fulfilling the SSI policy in December 2005, British Telecom Openreach (BTO) was created as an agreement between BT and the UK government in 2006 [60,61]. The purpose of BTO was to oversee access of ISPs to BT exchanges to deliver their respective broadband services, e.g., Talk, $\mathrm{O} 2$ and Sky broadband needed access to BT exchanges to enable their ADSL broadband service [60,61].

Along with the formation of BTO, the Scottish Government initiated an e-procurement project in 2006 to enhance broadband opportunities for Scottish SMEs (e.g., resources and support) [62,63]. After a critical analysis of this project, Dutra et al. [62] identified potential issues of centralisation and skill gaps [62]. The Scottish Government [63] identified over $90 \%$ of Scottish businesses as broadband adopters. These businesses adopted broadband for business operation purposes (Scottish Government, 2019). Online sales figures for Scottish SMEs increased faster than larger businesses in Scotland, where this information was retrieved from government studies from 2004 to 2008 [63]. This document highlights that $26 \%$ of UK businesses had access to a maximum speed of 2 megabits per second (Mbps). Only 14\% of the companies received broadband speeds of over $10 \mathrm{Mbps}$ [63]. This information provides evidence to support the overall dissatisfaction of Scottish businesses with broadband [63].

\subsubsection{7}

In 2007, the European Commission (European Regional Development Fund) allocated just under 43 million Euros for the Lowlands and Uplands project (for example, Lowlands and Uplands area of Scotland) [64,65]. The European Regional Development Fund allowed the UK government to pledge in 2009 of delivering a minimum of $2 \mathrm{Mbps}$ broadband to $100 \%$ of UK premises by 2012 [66-68]. However, the UK government scrapped this pledge due to continually missing targets (key milestones in achieving the commitment) in 2011 [66-68].

\subsubsection{0}

In parallel to the pledge made in 2009, the Scottish Government published the "A Digital Ambition for Scotland" policy in October 2010 [65]. This policy had two main objectives. The first objective consisted of making next-generation broadband available to $100 \%$ of the Scottish population by 2020 [65]. The second objective was to ensure that the rate of broadband uptake by people in Scotland was equal to/above the UK average by 2013. The rate of broadband uptake in Scotland by 2015 was targeted to be the highest amongst the UK nations $[63,69,70]$. The first objective has not yet been achieved, as the deadline was in 2020. The second objective of broadband uptake in Scotland equaling/surpassing the UK average by 2013 and being the highest amongst the UK nations by 2015 was not achieved either [71].

This policy also initiated a series of projects for improving broadband connectivity in rural areas within the South of Scotland $[63,65,70]$. However, the Scottish Government was aware that these projects were alone insufficient to improve connectivity in rural Scotland. The Government is working with partners across Scotland [63,65]. The Scottish Government was then looking to encourage sustainable community-led initiatives to improve broadband connectivity in rural Scotland [65]. The Scottish Government allocated one million Euros towards the rural Scotland broadband connectivity improvement project of the LEADER scheme $[63,65,70]$. This investment was intended to support small-scale, community-driven projects in rural areas. The Scottish Government aimed to improve connectivity and bring faster broadband to rural communities $[63,65]$. However, no projects within the policy focused on improving broadband adoption/use in rural Scotland. 


\subsection{Policies and Strategies, Projects and Programs from 2011 to 2016}

Policies/strategies, projects, and programmes focusing on broadband connectivity/take up/use in rural Scotland from January 2011 to December 2016 are identified and discussed below.

\subsubsection{1}

During the period of the "A Digital Ambition for Scotland" policy unveiled in 2010, the European Commission [72,73] introduced the "Basic broadband for all citizens by 2013" policy in 2011. The purpose of this policy was to deliver a minimum of $2 \mathrm{Mbps}$ broadband at an affordable price to all member states in Europe (including Scotland) [72-75].

The 2013 target for the European Commission policy was in line with the 2013 target (increasing broadband adoption/use up to the same level as the UK average) for the "A Digital Ambition for Scotland" policy introduced in 2010 [72]. This policy achieved its target of delivering basic broadband for all EU citizens by 2013 [72-75].

The Scottish policy branching out from the European Commission [72] policy of "Basic broadband for all citizens by 2013" was the "Scotland's Digital Future: A Strategy for Scotland" was created in 2011 [75]. Through this policy, the Scottish Government [75] was looking to realise its ambition of Scotland being recognised as world-class for digital technology in a wide variety of areas, e.g., e-health, e-learning, and e-government $[67,75,76]$. To achieve this ambition of offering world-class digital services, the Scottish Government [75] in this policy acknowledged that the improvement of broadband connectivity across Scotland, especially in more isolated and rural areas, was a prerequisite.

In the "Scotland's Digital Future: A Strategy for Scotland" policy, the Scottish Government recognises that good broadband connectivity enables economic growth in rural areas $[67,75,76]$. The policy also identifies that parts of rural Scotland cannot exploit or benefit fully from digital opportunities where the combination of poor connectivity and training to use broadband can lead to digital exclusion for many rural residents $[67,75,76]$. Therefore, rural areas lose their competitive advantage, making them less attractive locations for business $[67,75,76]$. Despite outlining measures to improve broadband connectivity and acknowledging the challenges of delivering broadband in rural Scotland, the policy does not discuss broadband adoption/use in rural Scotland.

In 2011, as part of the "Scotland's Digital Future: A Strategy for Scotland" policy, BTO pledged broadband with speeds of $100 \mathrm{Mbps}$ being delivered to 2.5 million new households by $2015[67,75,77]$. However, this pledge was not realised as BTO reached 250,000 homes by $2015[67,76,77]$.

\subsubsection{2}

Along with the failed BTO pledge, the previous failed Scottish Government pledge from 2009 (pledge of a minimum of $2 \mathrm{Mbps}$ broadband to 100\% UK premises by 2012) was reinstated by the coalition government in 2012 with a new target of a guaranteed speed of $24 \mathrm{Mbps}$ 'Superfast broadband' to $90 \%$ of the UK population by $2015[67,77]$. However, again, the Government could not deliver on its promise to provide $24 \mathrm{Mbps}$ to $90 \%$ of the UK population by 2015 . It revised its target of $24 \mathrm{Mbps}$ delivery to $95 \%$ of the UK population by $2017[67,77]$.

During the era of the coalition government in 2012, the Scottish Government proposed a 2020 plan of providing next-generation broadband across Scotland [40]. This initiative by the Scottish Government collaborated with Visit Scotland and the Highlands and Islands Enterprise $[40,77]$. The Government aimed to improve conditions for rural SMEs adopting broadband $[67,77,78]$. In this 2020 plan, considerable attention by the Scottish Government was given to the development of infrastructure in rural areas over urban areas, where there were calls for the installation of Fibre and 4G networks in rural Scotland $[67,77,78]$. The implementation of the 2020 plan led to the availability of an improved broadband service around Scotland $[67,77]$, therefore making broadband adoption/use more attractive to rural SMEs in Scotland $[67,78]$. 
3.2.3. 2013

After the success of the 2020 plan, the Scottish Government invested $£ 410$ million into the Digital Scotland Superfast Broadband (DSSB) programme in 2013 [40,67]. The purpose of the DSSB programme was to install and set up the infrastructure necessary and required to deliver faster broadband speeds to as much of the population as possible in areas that were not targeted for the commercial rollout of fibre broadband [40,67]. The DSSB programme was a crucial part of the Scottish Government's aim of ensuring that Scotland achieved a reputation as a world-class digital nation by 2020, e.g., "Scotland's Digital Future: A Strategy for Scotland" policy [75].

The DSSB programme was initiated through two separate projects: the Highlands and Islands programme and the Rest of Scotland programme [62] (Superfast Broadband Digital Scotland, 2019). Contracts were signed between the Scottish Government and BT to activate these projects in 2013 [40]. The Digital Scotland Superfast Broadband programme aimed to bring "fibre broadband" to $95 \%$ of Scottish premises by the end of 2017 [40,67]. Audit Scotland asserted the realisation of this target [40]. The DSSB programme led to 890,000 premises in Scotland being connected, which was $34 \%$ of premises in Scotland [40,67]. The DSSB programme was re-initiated in September 2019, whereby the overall expenditure on the programme was estimated to be around $£ 442$ million $[40,67,78]$.

\subsubsection{5}

During the running of the DSSB Programme, the then UK Prime Minister David Cameron in 2015 made it a legal requirement for the whole UK population to have access to affordable and reasonable quality broadband [79]. Therefore, the Universal Service Obligation (USO) was created to ensure access for all UK residents by $2020[67,80]$. The USO also acted as a primary policy for delivering "decent broadband" connections to those properties that could not be reached by the commercial or public-funded rollout of superfast broadband, e.g., areas in rural Scotland [67,79]. The minimum quality parameters for the broadband service rollout associated with this USO-driven initiative were $10 \mathrm{Mbps}, 1 \mathrm{Mbps}$ upload speed, and an allowance of 50 users to share one bandwidth $[79,80]$. The USO was made available to UK premises without access to connections that met the minimum quality parameters $[79,80]$. Home/business owners must register under the scheme to receive a broadband connection $[67,79,81]$ to benefit from the USO service.

During the reign of David Cameron in 2015, the UK government played a significant role in initiating discussions to separate BT and BTO to ensure a more level playing field for other ISPs looking to deliver their service through BTO controlled exchanges [82]. The separation between BT and BTO was completed in 2016 [67,82]. This separation improved broadband activation times for ISPs using BTO exchanges and ISPs needing access to deals to resolve technical issues, e.g., broadband speed and quality issues $[67,82]$. These improvements led to an improved experience for broadband adopters in the UK in terms of initial broadband take-up (faster broadband activation) and consistent broadband use (speedier resolution of technical issues) [67,82].

In 2015, the UK government introduced "the Better Broadband" scheme, a UK-wide voucher scheme initiated in $2015[67,83]$. The purpose of this scheme was to provide an affordable and basic broadband installation to homes/businesses that were unable to access a broadband service with a speed of at least $2 \mathrm{Mbps}[67,83]$. This scheme defined an affordable broadband connection as one that costs the customer no more than $£ 400$ in the first year [67,83]. This included hardware, installation, and monthly fees [83]. This scheme was typically used to access a satellite or wireless broadband connection and support community fibre projects [67]. The Better Broadband Scheme has been extended till 31st December $2019[67,83]$. This scheme represents the UK government's commitment to ensuring that every property in the UK has access to broadband connections with a minimum speed of 2 Mbps [67,83]. However, in January 2018, Ofcom reported that $0.5 \%$ of UK businesses/homes (155,000 business/homes) did not have broadband speeds of 2 Mbps [67,83]. 
Despite steps taken by the UK government in 2015 to improve broadband connectivity in the UK, the UK government acknowledged in 2016 that 5.7 million UK customers were not receiving broadband that met Ofcom's $10 \mathrm{Mbps}$ minimum speed criteria [15]. In response to this, government officials revealed a $£ 400$ million full-fibre infrastructure fund, where they guaranteed that a further 2 million homes and businesses would have access to fibre broadband [15,67]. They also pledged another $£ 700$ million to develop 5G (5th Generation) and further rollout of fibre connections [15,67]. The UK government asserted that rural areas with broadband access issues would not automatically receive the broadband infrastructure rollout. Instead, homes/businesses can request the USO to obtain essential and affordable $2 \mathrm{Mbps}$ broadband [67,77]. The USO pledge made by David Cameron in 2015 was then abandoned as the Government claimed that some rural communities do not want a broadband connection $[67,77]$.

\subsubsection{6}

In September 2016, the European Commission [73] unveiled the policy of "Connectivity for a European Gigabit Society". This policy addressed the availability and take-up of high capacity networks, which enabled the widespread use of new products, services, and applications in the Digital Single Market $[73,84,85]$. The deadline for this policy is $2025[73,84,85]$, where the three main objectives are access to 1 Gigabyte per second (Gbps) for all schools, transport hubs, and primary providers of public services and digitally intensive enterprises [72]. Access to speeds of at least $100 \mathrm{Mbps}$ to be upgraded to $1 \mathrm{Gbps}$ for all European homes $[73,84,85]$. Consistent and uninterrupted 5G wireless broadband coverage for all urban areas and major roads and railways [72].

While the European Commission [72] was promoting its "Connectivity for a European Gigabit Society" policy during 2016, in Scotland, the DSSB project reported its success in achieving its initial target of delivering access to fibre broadband to $85 \%$ of Scottish premises by March 2016 [75]. The DSSB project also claimed its status for being on track to deliver access to 95\% of Scottish premises by the end of 2017 (Scottish Government, 2019). Due to this programme, over 750,000 homes and businesses across Scotland now have fibre broadband [75].

The DSSB project provided $£ 7.5$ million in funding and support towards the Highlands and Islands Enterprise in launching the Community Broadband Scotland (CBS) project to develop superfast broadband solutions for areas where DSSB could not provide coverage [75]. An investment of $£ 80,000$ was made by Community Broadband Scotland (CBS) in 2016 to enable an upgrade to the current Tiree broadband network $[79,80]$. This situation led to broadband availability with up to $30 \mathrm{Mbps}$ in Tiree $[75,79,80]$. Eventually, the total cost incurred by this project for improving broadband in Tiree went up to $£ 91,000$ [79]. The additional funding of $£ 11,000$ came from the Tiree Community Development Trust (CDT) $[79,80]$. Due to a lack of U.K./Scottish Government focus on improving broadband infrastructure in Tiree, Tiree CDT took it upon themselves to improve broadband infrastructure [75]. This step led to an increase in broadband take-up by businesses in Tiree and eventually led to the rise in the number of companies in Tiree $[79,80]$. However, through their case study research, Gerli and Whalley [21] explain that public-private partnerships do not always guarantee success in improving broadband adoption and regular broadband use in a given area.

In 2016, the DSSB also supported Scotland's "Mobile Action Plan" project [75]. The purpose of this project was widespread mobile connectivity to support superfast broadband for a world-class digital Scotland [75]. A Mobile Action Plan was agreed upon between DSSB and four leading mobile operators from the UK in June 2016 [75]. This collaboration between Government and industry was the first to improve widespread mobile connectivity [75]. 


\subsection{Policies and Strategies, Projects and Programs from 2017 onwards}

\subsubsection{7}

In 2017, the European Commission unveiled the policies of "Coverage of Next Generation Networks (NGN): 30 Mbps or more for all citizens by 2020" and "Use of Next Generation Networks (NGN): $100 \mathrm{Mbps}$ or more by $50 \%$ of households by 2020" [72]. The purpose of these two policies was to ensure the delivery of NGN so that a minimum of $30 \mathrm{Mbps}$ broadband speeds were available to $100 \%$ of the EU premises (which included rural Scotland) and $100 \mathrm{Mbps}$ broadband speeds were open to at least $50 \%$ of the EU population [72]. In these two policies, the idea of "Smart Villages" was promoted to eliminate the digital divide $[21,67,72]$. This result was achieved through fast broadband, which led to the revitalisation of rural areas and boosting links between urban and rural populations on a personal and business level $[67,72,86]$.

After the European Commission [72] unveiled the two NGN policies in 2017, BT invested $£ 3$ billion to roll out $100 \mathrm{Mbps}$ broadband to 3 million premises by the end of $2020[67,87]$. This situation was initiated through two pilots fibre-to-the-premises (FTTP) projects funded by BT $[67,87]$. These consisted of building Fibre from new nodes off central fibre spines within the local exchange direct to local properties [67,87]. Additionally, the UK government worked with BT on a project consisting of $4 \mathrm{G}$ drones and balloons, leading to improved broadband connectivity within all rural areas in the UK $[67,84]$.

During the activity through policies and projects run by the European Commission and the UK government, the Scottish Government introduced the "Realising Scotland's full potential in a digital world: a digital strategy for Scotland" policy in 2017 [88]. The "Scotland's Digital Future: A Strategy for Scotland" policy from 2011 focused on improving broadband connectivity [75]. However, the "Realising Scotland's full potential in a digital world: a digital strategy for Scotland" policy from 2017 focused on having a more digital philosophy, highlighting the Scottish Government's focus directed away from improving broadband connectivity [88]. Despite this change in direction between 2011 and 2017, through the "Realising Scotland's full potential in a digital world: a digital strategy for Scotland" policy, the Scottish Government invested $£ 10.3$ billion to deliver $30 \mathrm{Mbps}$ broadband to $100 \%$ of premises in Scotland by 2021 [88].

In the "Realising Scotland's full potential in a digital world: a digital strategy for Scotland" policy, Scottish Government officials acknowledge "Economic success demands that our ability to benefit from digital is not limited by where we choose to live or work." [88]. The Scottish Government reported a target of superfast broadband (30 Mbps) being delivered to a minimum of $43 \%$ of Scottish rural premises and delivering an average speed of $15 \mathrm{Mbps}$ in rural Scotland by 2021 [88]. Despite acknowledging the policy towards improving broadband connectivity in rural Scotland, no project solely focuses on improving broadband adoption/use in rural Scotland.

This target of $30 \mathrm{Mbps}$ broadband speeds to 100\% Scottish premises by 2021 was also echoed by BT. Openreach $[89,90]$. The BTO team was looking to achieve this through re-using and extending the current network to reach more isolated villages [67,89]. This was made possible through BT's $£ 600$ million investment [89]. Through Ofcom figures, BT highlighted the inability of 1.4 million Scottish households in getting broadband speeds of $10 \mathrm{Mbps}$, and BT was planning to resolve this problem through a $£ 600$ million investment $[67,91]$. However, a group of U.K./Scottish Members of Parliament (MPs) disputed these broadband speeds and availability figures. They believed that a further 5.3 million households were not motivated to take up faster broadband [89]. These MPs added that some of these households may still not have speeds of $10 \mathrm{Mbps}$ even after the "Realising Scotland's full potential in a digital world: a digital strategy for Scotland" policy [88,89].

Therefore, the "Realising Scotland's full potential in a digital world is expressed. A digital strategy for Scotland" policy involved DSSB led projects in Scotland like the Balquhidder broadband community project [90,92]. This project was a combination of local Government, consumer initiatives, and investment [92]. This step by the population of Balquhidder highlighted that the initial government policy ("Realising Scotland's full 
potential in a digital world: a digital strategy for Scotland") for the area was insufficient in improving broadband infrastructure and adoption [90,92]. The project connected 200 households and businesses in Balquhidder to an enhanced broadband standard [67,90,92].

As part of the "Realising Scotland's full potential in a digital world: a digital strategy for Scotland" policy, the DSSB unveiled the "Choose Digital First" project in 2017 [90]. The Choose Digital First aimed to increase businesses' and individuals' use of digital technology and raise demand for services, helping to improve the commercial case for investment and delivering better outcomes for Scotland [90]. The Scottish Government then launched the R100 project as part of the DSSB programme in mid-2017 [90,93]. At the end of 2017, the Scottish Government announced an investment of $£ 600$ million for the initial phase of the R100 programme [67,93]. The initial procurement under the R100 programme was divided into three areas (North, Central, and South), where the first phase focused on rural Scotland [67,93]. The programme targeted 226,933 homes/businesses [67,93]. In August 2017, the DSSB programme launched the "Scottish 4G Infill" (S4GI) project, which was a result of a collaboration between the Scottish Futures Trust and the mobile industry [93]. The Scottish Government invested $£ 25$ million into the S4GI project to deliver future-proofed mobile infrastructure and services to 50 to 60 complete mobile 'not spots' by 2022 [90].

Outside of the "Realising Scotland's full potential in a digital world: a digital strategy for Scotland" policy, the communities in Altnaharra and Skerray within Sutherland took the initiative in creating their broadband infrastructure by digging up and installing approximately 4800 metres of cable $[67,87]$. This improvement led to a broadband service with up to $330 \mathrm{Mbps}$ which accommodated 130 people [87]. These speeds significantly improved from the original speeds of $0.5 \mathrm{Mbps}$ [67]. Initially, BTO was doing nothing to improve the $0.5 \mathrm{Mbps}$ broadband speed as the community was too small for an infrastructure upgrade $[87,90]$. Through this project, the community and businesses in Altnaharra gained a strategic alliance with BTO $[67,87]$.

The BDUK (Broadband Delivery UK) is an initiative under the UK government department of media and culture that has worked alongside the "Scotland's Digital Future: A Strategy for Scotland" and "Realising Scotland's full potential in a digital world: a digital strategy for Scotland" policies to improve broadband connectivity in Scotland [94]. The BDUK, up to 2018, has had $£ 1.7$ billion in public funding, where through this initiative, 4.8 million UK premises have gained access to superfast broadband ( $30 \mathrm{Mbps}$ ) by the end of March 2018 [94]. The BDUK initiative has given UK businesses an estimated $£ 12.28$ benefit for every $£ 1$ invested, leading to a total of $£ 9$ billion increase in turnover due to improved broadband connections [94,95].

Through the Broadband Delivery UK (BDUK) initiative in partnership with BT, the UK government announced a 440 million pounds investment (DSSB programme) towards improving broadband infrastructure $[94,96]$. This investment led to broadband with speeds of $24 \mathrm{Mbps}$ being made available to $95 \%$ of all UK businesses/homes by the end of 2017 [89,94]. The long-term plan for the BDUK initiative was to reach 97\% Scottish homes by 2020 [94,96]. As part of the BDUK initiative, $£ 18$ million was invested in Scotland to improve broadband speed and quality in rural areas [97,98]. The UK Cultural Secretary Karen Bradley has highlighted that the BDUK initiative has led to broadband availability in 670,000 Scottish homes within isolated areas [98]. She added that this improved broadband availability in isolated areas would improve broadband take-up in rural Scotland [97,98]. Scottish Cabinet Secretary for Rural Economic and Connectivity Fergus Ewing has claimed that the Scottish Government aims to deliver broadband coverage to $100 \%$ of all households in Scotland [97,98].

\subsubsection{8}

In July 2018, an agreement was made between the UK government and BT regarding the Ultra-fast broadband rollout $[68,99,100]$. Ultra-fast broadband is defined as a broadband connection with a download speed ranging from $300 \mathrm{Mbps}$ to 1 gigabit per second (gbps). There is solely a fibre line connection between the premises and local exchange $[68,99]$. 
The investment in this project was $£ 12$ billion, where 20 million UK households were targeted for Ultra-fast broadband connectivity by 2030 [100]. However, it should be noted that areas like rural Scotland are not the main focus of the Ultra-fast broadband programme where the UK and Scottish governments are relying on the Fibre to the Premises (FTTP) programme to fulfil the broadband connectivity requirements amongst households and businesses in rural Scotland $[68,99,100]$.

In the autumn of 2018, the UK government introduced the Autumn 2018 Budget, from which $£ 200$ million was put forward for investment towards piloting innovative methods involving the installation of full-fibre broadband through the Rural Gigabit Connectivity Programme [101]. The purpose of the Rural Gigabit Connectivity programme was to deliver gigabit-capable broadband connections to crucial businesses and public buildings, including institutions like schools [68,99-101]. Additionally, this programme encouraged broadband providers to create additional connections to local homes/businesses [101].

\subsubsection{9}

It is reported by Ofcom [101] that at the start of 2019, 20 per cent of Scotland's premises had no access to 4 th Generation (4G), where these premises were predominantly in rural areas. Additionally, $0.2 \%$ of Scottish premises were reported to have no access to either $10 \mathrm{Mbps}$ broadband or 4G broadband [101,102]. From October 2019, giant telecommunications providers like Vodafone, Three, and EE have begun to offer 5th Generation (5G) broadband to customers. However, this service is not widely available in rural Scotland [101,102].

In May 2019, the UK government introduced the Rural Gigabit Connectivity (RGC) programme [101]. The purpose of the RGC programme was to deliver gigabit broadband connectivity to isolated/remote areas in the UK, which were unlikely to benefit from commercial development, e.g., Vodafone investing in fibre-optic infrastructure in rural Scotland [101,102]. The UK government allocated $£ 5$ billion to ensure broadband connectivity in areas hard to reach by ISPs or current broadband rollout programmes like the R100 [101]. This programme prioritised improving connectivity in schools and hospitals in rural areas. The RGC programme initiated the Local Full Fibre Network Programme (LFFN) in rural Scotland from May 2019 onwards [101]. The LFFN programme has allocated over $£ 200$ million to local projects in rural Scotland dedicated to improving broadband connectivity, and it has also allocated $£ 67$ million towards a Gigabit Voucher Scheme [101]. This scheme aimed to support rural-based SMEs (small to medium enterprises) and local communities to improve broadband connectivity in the area, e.g., the Balquhidder project [101].

As of August 2019, the Scottish Government has allocated a further $£ 600$ million towards ensuring improved coverage of superfast broadband (minimum speed of $30 \mathrm{Mbps}$ ) across premises in Scotland, especially premises in rural Scotland, to achieve $100 \%$ superfast broadband availability in Scotland as part of the R100 programme initiative [101].

\subsubsection{0}

As of March 2020, the universal broadband service was implemented by the UK government, where households/premises with a download speed of fewer than $10 \mathrm{Mbps}$ and upload speed less than $1 \mathrm{Mbps}$ became entitled to request an upgrade in the broadband infrastructure for the property [101]. The broadband universal service initiative was especially relevant to ensuring that the broadband needs of households and businesses in rural Scotland were met, e.g., the availability of consistent broadband service in terms of speed and quality $[101,102]$. Despite the expansion of $4 \mathrm{G}$ broadband connectivity till the end of 2020 by the Scottish Government, Ofcom [101] reported in their Connected Nations 2020 report that 40,000 premises in Scotland are still unable to access $10 \mathrm{Mbps}$ speed broadband, where the vast majority of these 40,000 premises are based in rural Scotland.

\subsubsection{1}

Currently, superfast broadband (defined as broadband with a minimum speed of $30 \mathrm{Mbps}$ ) is available to over $92 \%$ of premises in Scotland. However, the availability of 
superfast broadband for businesses in Scotland is lower at 83\% [101,102]. Additionally, there is a big difference in access to superfast broadband between urban and rural-based premises, where there is $97 \%$ availability for urban premises compared to $67 \%$ for ruralbased premises. Therefore, despite the overall high availability of superfast broadband in Scotland, there is scope for improvement in rural Scotland, especially businesses in rural Scotland [101,102]. The last year (2020-2021) has seen substantial growth in the availability of superfast broadband in rural areas like the Highlands and Islands. However, the growth in the availability of superfast broadband in areas like Orkney and the Outer Hebrides is lagging [101,102].

The keywords inputted into Google/Google Scholar each year for government policy for improving broadband access/use in rural Scotland during the January 2006-May 2021 period, and the related sources are presented in the Table 2 below.

Table 2. Google Scholar Input Words-Government Policies on improvement Broadband Access/Use in Rural Scotland along with the generated sources.

\begin{tabular}{|c|c|c|c|}
\hline Google Scholar Input Words & Time-Period & Scottish Policy & Sources \\
\hline $\begin{array}{l}\text { Policy on improving broadband infrastructure } \\
\text { in Scotland }\end{array}$ & 2006-2009 & SSI policy & {$[36,51,61]$} \\
\hline $\begin{array}{l}\text { Policy on improving broadband accessibility } \\
\text { in Scotland }\end{array}$ & 2010-2016 & A Digital Ambition for Scotland & [71] \\
\hline $\begin{array}{l}\text { Policy on improving broadband use in } \\
\text { rural Scotland }\end{array}$ & 2011-2016 & Scotland's Digital Future: A Strategy for Scotland & {$[67,77]$} \\
\hline $\begin{array}{l}\text { Government policy on improving broadband use } \\
\text { in rural Scotland }\end{array}$ & 2017 & $\begin{array}{l}\text { Realising Scotland's full potential in a digital } \\
\text { world: a digital strategy for Scotland }\end{array}$ & {$[38,88,92]$} \\
\hline $\begin{array}{l}\text { Government policy on improving broadband } \\
\text { access and use in rural Scotland }\end{array}$ & 2018 & Ultra-fast broadband policy & {$[63,68,103,104]$} \\
\hline $\begin{array}{l}\text { Government policy on improving broadband } \\
\text { access and use in rural Scotland }\end{array}$ & 2019 & Rural Gigabit Connectivity (RGC) programme & [101] \\
\hline $\begin{array}{l}\text { Government policy on improving broadband } \\
\text { access and use in rural Scotland }\end{array}$ & 2020 & Broadband Universal Service Initiative & [101] \\
\hline
\end{tabular}

3.4. Conflicting Progress Reports on Broadband Roll out between English and Scottish Governments

Different political figures have varying opinions regarding the progress on superfast broadband allocation in Scotland. For example, in September 2017, Matt Hancock, the UK Government's then Digital Minister, commented that Scotland's progress on the rollout of superfast broadband was behind the rest of the UK [67,105]. In October 2017, the Scottish Government's Cabinet Secretary for Rural Economy and Connectivity, Fergus Ewing, explained that progress in Scotland in 2016 was faster than any other part of the UK where he added that we are on track to meet our target of 95\% coverage by the end of 2017 [105]. However, the UK. Digital Minister Matt Hancock stated that UK Government funding for full-fibre networks would go directly to local authorities in Scotland rather than the Scottish Government [40].

Matt Hancock explained that the Scottish Government had had more than three years to use the previously allocated $£ 20$ million of UK taxpayers' money, which could have improved broadband coverage in Scotland [67]. Therefore, he justified the decision to allocate funding for the Next Generation of broadband technology of entire Fibre to local authorities across Scotland, which has already been carried out in England [67,68]. There is an inconsistency between the UK and Scottish Government's reports on progress made in improving broadband services in Scotland [106]. For example, the Scottish Government and BT state that they are ahead of the targets set in the R100 policy [106]. However, the UK government disagrees with this statement and identifies the broadband rollout in Scotland as three years behind other areas in the UK $[106,107]$. This highlighted contradiction between governments needs to be clarified through further research. 


\section{Policy Analysis}

\subsection{Government Policies}

All European, UK, and Scottish policies and their respective projects, dates and status (e.g., complete or incomplete) during the post-January 2006 era (after activating a minimum of $512 \mathrm{kbps}$ broadband availability to $99 \%$ of Scotland in December 2005) are presented in Table 3.

Table 3. Policies on improving broadband connectivity/adoption/use in remote-rural Scotland (Jan 2006-May 2021).

\begin{tabular}{|c|c|c|c|}
\hline Time-Period & European Policy & Scottish Policy & Projects \\
\hline 2006-2009 & & S.S.I. policy & B.T.O. established \\
\hline 2010-2016 & & A Digital Ambition for Scotland & \\
\hline 2011-2016 & Basic broadband for all citizens by 2013 & $\begin{array}{l}\text { Scotland's Digital Future: A Strategy } \\
\text { for Scotland }\end{array}$ & $\begin{array}{c}2020 \text { plan } \\
\text { DSSB } \\
\text { Highlands and Islands Rest } \\
\text { of Scotland } \\
\text { U.S.O. } \\
\text { Mobile Action Plan } \\
\text { CBS. }\end{array}$ \\
\hline 2016 & Connectivity for a European Gigabit Society & & \\
\hline 2017 & $\begin{array}{c}\text { Coverage of Next Generation Networks } \\
\text { (NGN): } 30 \text { mbps or more for all citizens } \\
\text { by } 2020\end{array}$ & $\begin{array}{l}\text { Realising Scotland's full potential in a digital } \\
\text { world: a digital strategy for Scotland }\end{array}$ & $\begin{array}{c}\text { DSSB } \\
\text { FTTP } \\
\text { R100 } \\
\text { Balquhidder project } \\
\text { Choose Digital First } \\
\text { S4GI }\end{array}$ \\
\hline 2017 & $\begin{array}{l}\text { Use of Next Generation Networks (NGN): } \\
100 \text { Mbps or more by } 50 \% \text { of households } \\
\text { by } 2020\end{array}$ & & \\
\hline 2018 & & Ultra-fast broadband policy & $\begin{array}{l}\text { Fibre to the Premises (FTTP) } \\
\text { programme }\end{array}$ \\
\hline 2019 & & $\begin{array}{l}\text { Rural Gigabit Connectivity (RGC) } \\
\text { programme }\end{array}$ & Gigabit Voucher Scheme \\
\hline 2020 & & Broadband Universal Service Initiative & \\
\hline
\end{tabular}

Since the success of the Broadband for Scotland Rural and Remote Areas (SSI) policy in December 2005, there have been policies and projects unveiled on a European/U.K./Scottish level to improve broadband connectivity in Scotland [90]. These policies and projects have played a significant role in improving broadband connectivity in Scotland. For example, $30 \mathrm{Mbps}$ broadband is available to over $90 \%$ [90]. The BDUK initiative on a UK government level along with the DSSB programme on a Scottish level has been crucial in improving broadband availability (over 99\% broadband availability with a minimum of $2 \mathrm{Mbps}$ ) along with raising the overall quality of available broadband in Scotland (30 Mbps speed broadband available to over $90 \%$ of Scotland) [90]. However, there have been no policies or projects that have directly focused on improving broadband adoption/use in rural Scotland (Theme 1), which is essential as broadband non-adoption by rural residents can lead to rural Scotland being digitally excluded from the modern world, for example, broadband takes up in rural Scotland is lower than urban areas [51].

Another theme identified from the policy analysis in this article was the change in direction from the "Scotland's Digital Future: A Strategy for Scotland" policy from 2011, which focused on improving broadband connectivity in Scotland to the promotion of a more digitally-driven lifestyle amongst residents within the "Realising Scotland's full potential in a digital world: a digital strategy for Scotland" policy from 2017 [90]. This change in focus highlighted that the Scottish Government was satisfied with broadband connectivity compared to 2011. However, even during the "Realising Scotland's full potential in a digital world: a digital strategy for Scotland" policy, community-led projects have been unveiled to improve broadband connectivity in rural areas in Scotland, which could not be covered by 
government policy or projects [90]. The emergence of community-led projects to improve broadband connectivity questions the Scottish Government's contentment towards overall broadband connectivity in Scotland.

The third theme identified from the policy analysis was the disagreement between the UK and Scottish Government officials regarding broadband rollout. Scottish officials claimed that the projects are ahead of schedule [106,107]. However, UK government officials claimed that the projects were behind schedule [106,107]. Officials from the UK government also assert that there will be a change in how funds for improving broadband connectivity in Scotland are allocated. They will be distributed amongst local councils rather than the Scottish Government [106,107].

This conflict between the UK and Scotland governments, and past failed pledges by the UK government, raise concerns over the accuracy of the information provided regarding the progress of broadband rollout in Scotland. Additionally, the Scottish Parliament is allocated approximately 40 billion pounds per annum by the UK government (based in Westminster) to manage its spending on different resources found in Scotland, for example, broadband internet infrastructure, emergency services, and public transport [108]. The Scottish Government controls $60 \%$ of the public spending in Scotland, where the UK government holds the remaining $40 \%$ [90,108]. Therefore, the review of broadband connectivity/take up related policy in a rural Scotland context in this article highlights that the UK government (Westminster) has the responsibility and authority regarding the improvement of broadband infrastructure and authorising broadband rollout in Scotland, for example, the Digital Scotland Superfast Broadband and R100 projects [109]. However, the Scottish Government (Holyrood), with monies and authority allocated by Westminster, has the role of overseeing/managing each policy/project till its conclusion to ensure improved broadband connectivity/take-up in rural Scotland. For example, with the funds authorised by Westminster, the Scottish Government has targeted improving broadband connectivity and use in remote rural areas through the Digital Scotland Superfast Broadband and R100 projects $[106,107,109,110]$. In other words, all the broadband-related projects have been authorised by the UK government through Westminster, releasing the appropriate and required funds; however, the Scottish Government oversees each project's day-to-day running and reports/has reported progress back to Westminster.

As identified in the methodology section, Bardach's Eightfold Pathway analysis was applied to the results and emerging themes from the policy analysis in this article. This analysis method consists of the steps of: (1) Define the problem; (2) Assemble some evidence (e.g., find information/data that can allow you to analyse the problem); (3) Construct alternatives (for example, identify possible methods available to resolve the problem); (4) Select the criteria (for example, prerequisites/key indicators to make a decision); (5) Project the outcomes (possible outcomes to each suggested method are predicted); (6) Confront the trade-offs (e.g., how did the possible outcomes compare to each other?); (7) Decide (for example, this step is taken based on the best option identified in step 6); (8) Tell your story (e.g., when you need to convince someone else in addition to yourself regarding the decision made) [58].

Bardach's analysis was applied to the policy analysis in this research as it can be used as a guideline/road map to identifying solutions for problems identified in a policy analysis while allowing flexibility for users to personalise it to suit the requirements of their research studies [58]. For example, Bardach's analysis can be customised for social science and science research [58]. Therefore, Bardach's analysis was applied in this research study to aid the researcher in establishing a direction for future steps based on the problems identified from the policy analysis. The results from Bardach's research application are presented in Table 4 .

The results from Bardach's analysis of the policy analysis/review findings in Table 4 encourage the need for further research to eliminate the confusion created by the conflicting views from the UK and Scottish Governments on broadband connectivity progress in Scotland. Bardach's analysis also promotes further Research to determine the role of the 
Scottish Government in improving broadband adoption and broadband use within remoterural Scotland as there is no content in this area within policy documents for the period January 2006-Current (May 2021).

Table 4. Policy Analysis of EU/UK/Scottish Government documents on broadband (January 2006-May 2021).

\begin{tabular}{|c|c|}
\hline Bardach's Pathway Steps & Explanation \\
\hline Define the problem & $\begin{array}{l}\text { A minimum of } 512 \mathrm{kbps} \text { broadband was made available to } 99 \% \text { of Scotland in December } 2005 \text {. However, the } \\
\text { guaranteed } 512 \mathrm{kbps} \text { is insufficient for rural businesses in running daily operations. }\end{array}$ \\
\hline Assemble some evidence & $\begin{array}{l}\text { Policy documents from January } 2006 \text { to Current (May 2021) were reviewed to identify steps taken by the } \\
\text { Government to improve broadband connectivity in remote-rural Scotland, e.g., has the minimum guaranteed } \\
\text { speed improved from } 512 \text { kbps since December } 2005 \text {. }\end{array}$ \\
\hline Construct the alternatives & $\begin{array}{l}\text { Various policies have been created and initiated to improve broadband connectivity in remote-rural Scotland, } \\
\text { reviewed in Table } 2 .\end{array}$ \\
\hline Select the criteria & $\begin{array}{l}\text { Policies created and initiated during January 2006-Current (May 2021). Additionally, the policies covered } \\
\text { connectivity in remote-rural Scotland. }\end{array}$ \\
\hline Project the outcomes & $\begin{array}{l}\text { All policies (in Table 2) have outlined projected targets and outcomes regarding when faster broadband will } \\
\text { be offered in Scotland (including remote-rural Scotland), e.g., the Scottish Government in the 'Realising } \\
\text { Scotland's full potential in a digital world: a digital strategy for Scotland' policy in } 2017 \text { reported a target of } \\
\text { superfast broadband ( } 30 \mathrm{Mbps} \text { ) being delivered to a minimum of } 43 \% \text { of Scottish rural premises and } \\
\text { providing an average speed of } 15 \mathrm{Mbps} \text { in rural Scotland by } 2021[39,63] \text {. }\end{array}$ \\
\hline Confront the trade-offs & $\begin{array}{l}\text { Through EU, UK, and Scottish policies, Scotland has reported a significant improvement in broadband } \\
\text { connectivity. However, no direct policy focuses on improving broadband adoption/use in remote-rural } \\
\text { Scotland. Additionally, the Scottish and UK governments are giving conflicting reports on Scotland's rollout } \\
\text { of broadband progress. }\end{array}$ \\
\hline Decide & $\begin{array}{l}\text { The UK and Scottish Governments need to agree on facts associated with the progress made on broadband } \\
\text { connectivity in remote-rural Scotland before reports on broadband upgrade delivery are released to } \\
\text { the public. }\end{array}$ \\
\hline Tell your story & $\begin{array}{l}\text { The emergence of the three themes, which involve no policy or project focusing on broadband adoption/use, } \\
\text { along with the confusion on progress made by the Scottish Government regarding improving broadband } \\
\text { connectivity and quality, highlights the requirement of Research to gain further clarification on these areas. }\end{array}$ \\
\hline
\end{tabular}

\subsection{Innovative Companies in Scotland}

The Scottish Government launched the Scottish Enterprise Open Innovation programme in 2016. The programme's focus was to increase the demand for innovative solutions to solve a range of business problems, especially crucial for businesses in isolated areas within Scotland. For the context of this paper, the innovative solution for communities (businesses/households) based in rural Scotland may involve promoting products via website/social media and communicating with customers/suppliers/stakeholders via email/social media, which is reliant on a reliable and fast broadband service (e.g., consistent connectivity and no lagging in service) $[10,14,23]$.

It should be noted that through this programme, the Scottish Government [111] was initially looking to support/aid 13 private businesses and public sector organisations through collaboratively working on designing and then launching a series of 'Innovation Challenges' for SMEs in Scotland. This initiative involved business owner-managers sharing their expertise, knowledge, insight, and ideas with the government and other fellow businesses on the programme [111]. The Scottish Government [111] encouraged large (50 or over employees as per the European Commission [86] definition) as well as smaller businesses (0-49 employees as per the European Commission [86] purpose) based in Scotland to engage with this programme. However, SMEs were the majority of the businesses that participated.

Through this programme, the Scottish Government [111] aimed for participant businesses to share risk and reward, collaborate, make connections, improve profits, and gain a competitive edge in their respective markets. Based on discussions by authors identifying the readiness of smaller businesses in comparison to their larger counterparts to engage in initiatives involving innovative solutions for their operations, it can be highlighted that such a programme would be crucial for the growth and survival of SMEs in rural Scotland, therefore leading to an increase in the overall rural economy of Scotland [21,22]. However, 
such participation can only be supported by an appropriate level of broadband coverage in terms of speed and consistent connection in rural Scotland. Otherwise, participation from rural-based businesses will be none/limited [14].

Dekkers et al. [112] agree with previous sources (e.g., Scotland Can Do [113] and Scottish Enterprise [114]) on points regarding the importance of open innovation amongst individuals/businesses for the greater good, e.g., health and wellbeing, along with national economic growth leading to business survival and job creation. However, as highlighted earlier by the Scottish Government [111], Dekkers et al. [112] explain that the implementation of an open innovation system is easy application into the operations of small to medium enterprises than larger businesses due to a lack of established or rigid systems and philosophies amongst management. This is a crucial finding as over $90 \%$ of the companies in rural Scotland are classified as micro-businesses. The openness of owner-managers of smaller businesses can only be accommodated with appropriate broadband coverage (e.g., consistent speeds and quality throughout rural Scotland) [111].

In terms of innovative companies in Scotland, there is currently a project (Remote Rehabilitation Service for Isolated Areas (ROSIA)) planned for execution in isolated areas within Scotland that will deliver a comprehensive service to patients in need of rehabilitation, new care pathways, and community support [113]. This project is crucial to ensuring the health and wellbeing of patients based in remote-rural Scotland; however, it is reliant on an appropriate level of broadband connectivity and broadband adoption/use in rural Scotland, e.g., the broadband service needs to be fast and consistent in quality (no regular disconnections or lagging service) to ensure that patients' needs are accommodated in an efficient and timely manner as dragging, or inconsistent broadband coverage may lead to severe consequences for patients requiring attention (critical condition or death) [113].

Scottish Enterprise [114] aims to improve the Scottish national economy and promote innovation amongst businesses/individuals, especially in isolated/rural areas, using broadband-driven technologies and applications. Additionally, as part of the "Innovative Challenges" programme delivered by the Scottish Government [115] in 2016, the Scottish Enterprise is currently working in partnership with Innovate UK and a range of other public sector institutions to support a series of innovation challenges presently faced by the business sector which will involve smaller businesses based in rural areas looking to expand their operations as well as survive in the long term. However, as mentioned earlier for the ROSIA project, fast and consistent broadband is crucial for engaging the population-based in rural Scotland where rural areas make up the majority of the landmass in Scotland, e.g., urban areas are the minority in terms of rural/urban classification of areas in Scotland $[63,116]$.

Similar to the Scottish Enterprise [115], the Scottish Government [116], through partnerships amongst departments / companies like Business Gateway, Skills Development Scotland, and Scottish Enterprise, offer businesses support in innovative solutions through collaboration opportunities with other companies and funding from the government/private institutions. As identified by various sources, most innovative solutions for businesses are linked to the availability and adoption/use of broadband of an appropriate speed and quality $[10,14,23]$.

\section{Open Innovation in Scotland}

Historical review and policy analyses cannot be fully exploited unless considered under the lens of innovation frameworks. Innovation plays an increasingly important role in our economy. It benefits both consumers and workers. It is essential to create better jobs, build a greener society, improve our life quality, and safeguard the countries' competitiveness on the world market. Innovation policy represents the link between research and technological development policy and industrial policy, and it aims to create a favourable environment for ideas to reach the market.

Even if the demand can be one of the significant sources of innovation, only in recent years have public policies been developed that use demand as a driver of innovative processes. 
It is possible to define a demand-oriented innovation policy when referring to all public measures to stimulate innovation or accelerate the diffusion of innovations by increasing the demand for innovation, defining new functional requirements for products and services and the best articulation of the demand itself.

This very general definition highlights the two possible dimensions of this policy: promoting both the generation of innovations and the diffusion of innovations. It also assumes a broad concept of innovation: creating something new in absolute terms on a global scale and for a single company or a single territory.

The following considerations justify the use of innovation policies focused on the demand side:

(a) Overcoming the failure of market mechanisms;

(b) Respond effectively to the needs of society;

(c) Promote the modernization of the production system;

(d) Promote the technological competitiveness of local production systems and create "lead markets".

Some economists have always supported "state entrepreneurship" [117]. Others ask for new nationalizations $[118,119]$ but still advocate a more decisive role for the state in some sectors, such as those where market failures occur [120].

Many economists have already highlighted how the return to a heavy role in the countries' economic life would have prohibitive costs [121-123]. However, the most relevant question is whether the state can directly manage entrepreneurial activities in today's complex economic context and, above all, whether it can directly manage the critical processes for the technological modernisation of the production system.

Efficiency issues might arise, including risks associated with corruption, political exploitation, and clientelism [124,125], which unfortunately have characterized many significant state holdings in the past. There are still considerations on the intrinsic slowness [126] that state organizations have in responding to the challenges of a highly dynamic environment where technological innovation is critical. In these contexts, it is necessary to know how to identify and seize opportunities in real-time, hire the best scientists globally, divest or retrain skills that are no longer adequate, and quickly connect and redefine alliances, projects, and investments. Public structures are often unable to guarantee this reactivity. The production chains-or "value chains" - are increasingly fragmented, globalised, and witness a growing mix between manufacturing and services [127]. Value chains are increasingly global in scope. The fragmentation of production along domestic and international value chains means that investments in technological innovation in the 1950s and 1960s [128], centralized in large vertically integrated manufacturing companies, are increasingly segmented between the multiple players in the production chains, from minor to medium-sized enterprises supplying intermediate goods to downstream users of intermediate goods, to enterprises providing logistics, communication, and marketing services to the supply chains. In recent years, the decentralisation of innovative processes [129] has also involved sophisticated research and development projects: companies increasingly feel the need to delegate research and development to the partners in the supply chain most in contact with foreign markets and who are therefore better able to grasp changes in their consumption and production needs in local markets. The very nature of innovations has changed radically within the supply chains that increasingly involve production and organisational processes and managerial practices sewn around the individual players in the value chain. The old linear innovation models have entirely disappeared, even for some time. It is no coincidence that many large private companies avoid directly conducting all research and development activities related to their sector: it is no longer efficient to do so, while it is more convenient to rely on decentralised or open innovation models. Recent research shows that companies with more decentralised research activities have the best performance and most significant market value [130,131]. 
The Government can and indeed must play a fundamental role in creating the conditions for these processes and markets to function in the best way, without distortion and as efficiently as possible.

First of all, by forming human capital of excellence in critical sectors for innovation, a task that private companies are not able to perform on their own.

Secondly, by helping small and medium-sized enterprises to enter value chains and absorb know-how within the supply chains, with network contracts in favour of the supply chains, measures that support the creation of fluid and accessible capital markets for companies. Who wants to invest in innovation and actors who wish to propose themselves as financial incubators (venture capital/business angel).

Third, by promoting partnerships between upstream and downstream businesses, including insurance instruments for small and medium-sized companies investing in risky innovation activities. Finally, by ensuring the modernization of the tangible and intangible infrastructure network in which the production chains operate.

These fundamental tasks for the state can effectively facilitate the technological and productive transformations of the contemporary economy, more than nostalgia for an ancient past as an entrepreneur state. These policies should constitute proposals for innovation within a political program that wants to go beyond catchy and reassuring slogans and knows how to face the challenges of the modern economy with competence and courage. With our heads turned to the future, and not to a past that-who knows why - we always tend to see much more brilliant than it was.

Scotland improved a range of direct strategies to support open innovation, including "Support and funding for open innovation" [132] and "Open Innovation Marketplace" [133]. However, one of the critical actions that contributed to turning the Scottish Government into an active player in the open innovation ecosystem is its strategic role in the broadband deployment that ensured fair competition and business survival in any country area. The previous sections of this research have demonstrated that this approach contributed to the private citizens' wellbeing and the businesses' survival and success, regardless of whether they were adopting closed or open innovation strategies. In Scotland, market failures have been addressed not only in a purely "welfare state" approach but a more comprehensive and strategic Open Innovation strategy. This plan included coordinated policies to target innovative businesses.

This support is powerful as it is targeted at overcoming market failures where the TLC providers had no incentives in creating adequate infrastructures. Smart cities cannot be developed without proper infrastructure, and the areas that are served by broadband, previously abandoned, can flourish again.

\section{Government Policy, IT Infrastructure, and Open Innovation}

In the last decade, the innovative processes of companies have undergone profound changes. The worsening of the economic crisis, the intensification of global competition, the reduction in the life cycle of new products and the consequent difficulty in supporting the growing expenses in research and development (R\&D) are just some of the causes of the change that has taken place in innovative enterprises processes and R\&D departments. In this turbulent environment, Open Innovation (OI) dynamics have begun to develop [48,134], flanked by a growing propensity to create collaborations for innovation with external parties such as companies, technology suppliers, but also competitors [135], universities and research centres [136,137], and up to the involvement of consumers and lead users [138], as well as policy-makers.

In this panorama, two lines of research have firmly streamlined and attracted particular interest from business management scholars: (a) Open Innovation [48,134] and (b) Innovation networks $[139,140]$.

In the early 2000s, Chesbrough's contribution [48] to Open Innovation developed exponentially, becoming a significant subject of study in management and innovation [141,142]. Moreover, this theme is still attracting significant interest in more recent management 
studies [143-146]. Open Innovation is increasingly integrated into business strategy studies $[147,148]$. Numerous scholars have recently focused on Innovation Networks by increasingly highlighting the relevance of external innovation processes and, in particular, on the development of partnerships, networks, and alliances for innovation [149-151].

Governments must assume the role of promoter of research and innovation [152], whose increase must be considered a significant objective for the growth of the countrysystem, as there is a close correlation between the lack of productivity of this and the low capacity for innovation that characterizes it. Tax credits [153] usually represent the main actions of government policies for investments in new CAPEX as part of signing innovation agreements and development contracts. Within the public contracts market, a mature public demand can be used as a tool to select a competitive offer both in terms of costs and in innovative content, thus favouring the conversion of research and development into productive assets.

Public tenders procedures are traditionally aimed at guaranteeing only the economy and efficiency in using public resources [154]. The general mistrust [155] of the public administration's ability to escape possible corruption has led the legislator to adopt detailed and binding legislation that minimises discretion.

Scotland capitalism still appears family type oriented [156]. Most companies are micro, small, or medium-sized, not active on the technological frontier, with a low propensity to risk [157].

In general, administrative complexity and the constant decrease in public investments are usually considered elements that directly hinder support for research and innovation. This aspect proves essential when referring to IT infrastructure. IT infrastructure comprises hardware, software, and networking, which are needed to run and manage enterprise IT environments. It can be deployed within a cloud computing system or an organization's structure.

The first phase for developing broadband or ultra-broadband, an essential prerequisite for developing 5G [158], is currently underway, and concern the areas where public intervention is required. In the case of Scotland, as demonstrated in this article, several regulatory provisions have been introduced to facilitate the deployment of broadband networks.

Throughout Europe, large TLC networks were built by public companies or private state concessionary companies in the first half of the 1900s. TLC networks then used copper cables. At that time, the choice of this model (public company or private company assignee of a public concession) was due to:

(a) Ensure that, by imposing specific investment obligations on the concessionaire (network coverage), an essential service such as the telephone connection was deployed even where there was no market convenience to create the infrastructure (universal service, as in the case of the electricity network);

(b) Avoid the risk of inefficient duplication of investments in the construction of an infrastructural network that was essentially a natural monopoly (such as rail, road, and electricity networks);

(c) Facilitate the mobilisation of the significant long-term capital (equity and debt) necessary for the construction of an infrastructure that would have guaranteed a return on the investments only after its construction, and would have allowed the cost of the investment to be depreciated only in the long term (and provided that it is used by a high percentage of potential end-users reached by the infrastructure network);

(d) Use the technical and organizational skills of companies, public or private, which traditional administrative systems (public bureaucracies) often did not have.

In many cases, later, the private concessionaires were acquired and aggregated into a state-controlled public concessionaire. The predominant role of the State, in the case of IT and TLC infrastructures, as well as in the case of transport infrastructures (railways, roads, highways, airports, and ports), usually responds to a precise reason: the State is, by its nature, a long-term patient investor. The Government is also interested in the positive externalities that network infrastructures, if well planned and well-conceived, 
produce (economic growth, social cohesion, quality of life, tourist attractiveness, etc.) [159]. Moreover, it is ultimately up to the Government to guarantee citizens' universal rights, everyday goods, and essential public services.

In the latter part of the twentieth century, the large public companies that owned and managed the TLC networks (still in copper, even if there was talk of optical fibre) were fully or partially privatised. In several European countries (such as France, Germany, Norway, and Sweden), the Governments nevertheless remained (and remains) the controlling shareholder (directly or through publicly-financed companies). In others (such as the UK, Spain, and Italy), the State has instead shifted the control to private individuals (although sometimes retaining some powers of intervention on strategic decisions or the shareholding of privatised companies through the so-called "golden share" or "golden power" [160]).

In the meantime, however, the business model of these companies had changed substantially. The large infrastructural networks had by now been built all over the country, and the long-term investments made to build them had been entirely or almost completely depreciated. The fundamental business of these companies had therefore become no longer the construction from scratch, but the network management, the provision of IT and TLC services, marketing (acquisition of new subscribers), and billing (billing of subscriptions and calls). Indeed, it is still necessary to invest in maintenance, completion (connection with new housing developments), and modernisation of the network. Nevertheless, it is no longer a significant "greenfield investment" [161]; it has become a brownfield infrastructure investment [162], financed with a share of the revenues generated by the management of the network and the sale of services.

Therefore, the weight of short-term shareholders (in the forefront of international investment funds), interested in short-term returns and short-term capital gains, increased; the weight of these shareholders soon has become prevalent, except in those countries (France, Germany, Sweden, above all) in which the State had retained the role of controlling or reference shareholder.

In most OECD countries, privatisation policies were generally accompanied by liberalisation policies: opening the service market to new entrants; they were guaranteed the right to access the existing infrastructure owned by the ex-monopolist operator (incumbent) [163].

The digital revolution that has taken place in recent years (Digital economy, Internet of things, Artificial intelligence, social networks, Blockchain, Industry 4.0, smart cities, smart homes, smart grids, telemedicine, e-government, e-education, and assisted driving cars) is also imposing a radical break concerning IT and TLC infrastructures. IT and TLC increasingly constitute the decisive infrastructures for each country's competitiveness, employment, and social cohesion, and therefore lasting, inclusive, balanced and sustainable growth. Only infrastructure networks entirely in optical fibre (FTTH) with decentralised architecture (and therefore equipped with local data processing devices, such as edge cloud computing or fog computing) will have the technical requirements necessary to use, Gigabit Society's products, services, and applications.

Therefore, the quality level of the universal connectivity service that should be ensured to citizens and businesses is changing again, overcoming the old minimum limits built based on obsolete economic and technological logic. Moreover, the business model changes again and radically. An Open Innovation approach Government-led policies prove critical.

It is not only a matter of managing existing infrastructural networks but also providing for their maintenance and completion and encouraging competition within the infrastructural typology of the incumbent. Building essentially new infrastructure networks is also necessary. Compared to the copper-TLC development, the modernisation of the broadband network includes constructing a new infrastructure (fibre) that replaces the copper one. This requires huge investments, which private operators are unable (or unwilling to) make. After so many decades, the need for long-term "greenfield investment" returns. 


\section{Discussion and Conclusions}

The purpose of this article was to critically review the important Scottish Government policy regarding broadband connectivity and use from January 2006 until the present day to determine the role of the Government in supporting broadband adoption and broadband use in remote-rural Scotland. The starting point of January 2006 was chosen as in April 2005. An agreement was signed between the Scottish Government and British Telecom to activate 378 telephone exchanges, finally achieved in December 2005 [36]. This agreement was a part of the "Broadband for Scotland Rural and Remote Areas Supply-Side Intervention (SSI)" policy initiated in 2001 [36,51,59]; the critical policies, the related strategies, projects, and programmes, were also considered. This policy analysis focused on Scotland (where the empirical work was conducted). However, EU and UK policies were also considered. The analysis considered the aim of each policy, its key deliverables (intended and achieved as appropriate) and, given the aim of this work, the mention of issues relating to rurality, broadband adoption/use, and related drivers and barriers.

The review of policies like "A Digital Ambition for Scotland" from 2010, "Scotland's Digital Future: A Strategy for Scotland", and "Realising Scotland's full potential in a digital world: a digital strategy for Scotland" throughout January 2006-May 2021, identified clear targets for delivering broadband connectivity in Scotland. All policies acknowledged the additional challenges of providing broadband connectivity or upgrades in rural Scotland. However, these policies have no straightforward projects that focus on improving broadband adoption/use in rural Scotland.

After reviewing the various policies during January 2006-May 2021, it can be noted that the development of broadband infrastructure in rural Scotland has been driven by feedback from the local rural populations (e.g., households/businesses) throughout Scotland $[67,105]$. The Scottish and UK government's have been supportive in improving broadband infrastructure to improve broadband adoption/take up amongst rural Scottish communities $[67,105]$. However, this policy analysis has also identified that due to conflicting views between the Scottish and UK governments, there has been a reluctance on a government level to further focus on broadband infrastructure development, which has been demonstrated by a more limited allocation of funds and focus/time by the UK/Scottish government from the execution of the Ultra-fast broadband policy (2018) onwards $[106,107]$. Therefore, rural populations have always welcomed improvement of broadband infrastructure in their local area, but the Scottish/UK government have over time became an obstacle against the improvement of broadband infrastructure due to an underlying belief that further developments may be counter-productive or surplus to requirements $[106,107]$.

The themes and associated problems that emerged from the policy analysis are reviewed in Table 5.

Table 5. Themes and problems emerge from the Policy Analysis (January 2006-May 2021).

\begin{tabular}{|c|c|c|c|}
\hline Theme & Theme 1 & Theme 2 & Theme 3 \\
\hline Explanation & $\begin{array}{l}\text { No policies exclusively focusing } \\
\text { on improving broadband } \\
\text { adoption/use in rural Scotland. }\end{array}$ & $\begin{array}{l}\text { The Scottish Government focuses less on } \\
\text { improving broadband coverage in the } \\
\text { latest policy (e.g., Realising Scotland's full } \\
\text { potential in a digital world: a digital } \\
\text { strategy for Scotland and Digital Charter } \\
\text { policies). The focus of the Government has } \\
\text { changed to the direction of promoting } \\
\text { digital connectivity amongst the } \\
\text { Scottish population. }\end{array}$ & $\begin{array}{l}\text { Conflicting information between the UK } \\
\text { and Scottish Governments regarding the } \\
\text { progress of the delivery of improved } \\
\text { broadband (e.g., connectivity, consistency, } \\
\text { and average speeds) in } \\
\text { remote-rural Scotland. }\end{array}$ \\
\hline Problem & Problem 1 & Problem 2 & Problem 3 \\
\hline Explanation & $\begin{array}{l}\text { Lack of broadband adoption/use } \\
\text { in rural communities can create a } \\
\text { further digital divide between } \\
\text { rural and urban communities. }\end{array}$ & $\begin{array}{l}\text { The emergence of new community-led } \\
\text { projects to improve broadband in rural } \\
\text { Scotland raises questions against the } \\
\text { Government's contentment on } \\
\text { broadband connectivity. }\end{array}$ & $\begin{array}{l}\text { This conflict in information regarding } \\
\text { rollout progress creates doubt and } \\
\text { confusion regarding any progress being } \\
\text { made, especially after failed government } \\
\text { pledges in the past. }\end{array}$ \\
\hline
\end{tabular}


The emergence of these three themes and problems from the policy analysis may have policy implications, highlighting a need for further research to clarify this confusion regarding the overall progress and status of broadband connectivity and take up in Scotland, especially remote-rural Scotland.

This article has achieved its purpose in critically reviewing the important Scottish Government policies involving broadband connectivity and use from January 2006 until the present (May 2021) by identifying themes and the associated problems. It further highlighted the benefits of broadband deployment in terms of the open innovation contribution provided by the Scottish Government. However, Bardach's analysis of policy review findings (Table 4) from this article encourages further research to clarify broadband adoption and broadband use in rural Scotland and clarify the reason behind conflicting views between the Scottish and UK governments regarding progress made on a broadband rollout in Scotland. From an Open Innovation perspective, the critical role played by the Scottish government was considered and proved successful.

Author Contributions: Conceptualization, S.A.M.G. and A.F.; data curation, S.A.M.G.; formal analysis, S.A.M.G.; investigation, S.A.M.G. and A.F.; methodology, S.A.M.G.; project administration, S.A.M.G.; resources, S.A.M.G.; supervision, S.A.M.G.; validation, A.F.; visualization, S.A.M.G.; writing - original draft, S.A.M.G.; writing — review and editing, S.A.M.G. and A.F. All authors have read and agreed to the published version of the manuscript.

Funding: This research received no external funding.

Institutional Review Board Statement: Not applicable.

Informed Consent Statement: Not applicable.

Conflicts of Interest: The authors declare no conflict of interest.

\section{References}

1. Webster, F. Theories of the Information Society; Routledge: London, UK, 2014.

2. Hanafizadeh, M.R.; Saghaei, A.; Hanafizadeh, P. An index for cross-country analysis of ICT infrastructure and access. Telecommun. Policy 2009, 33, 385-405. [CrossRef]

3. Antonelli, C. The network of networks: Localized technological change in telecommunications and productivity growth. Inf. Econ. Policy 1996, 8, 317-335. [CrossRef]

4. Slater, W.F., III. Internet History and Growth; Internet Society: Chicago, IL, USA, 2002.

5. Del Bo, C.; Florio, M. Infrastructure and Growth in the European Union: An Empirical Analysis at the Regional Level in a Spatial Framezork; Working Paper n. 2008-37; Department of Economics, Business and Statistics, University of Milan: Milan, Italy, 2008 ; pp. 1-31.

6. Hulsink, W. Privatisation and Liberalisation in European Telecommunications: Comparing Britain, the Netherlands and France; Routledge: London, UK, 2012.

7. Craig, W. The History of the Internet in a Nutshell. 2019. Available online: https://www.webfx.com/blog/web-design/thehistory-of-the-internet-in-a-nutshell/ (accessed on 3 July 2019).

8. Kwach, J. Importance of Internet in Our Life. 2018. Available online: https:/ /www.tuko.co.ke/263579-importance-internet-ourlife.html (accessed on 11 July 2020).

9. Fitzpatrick, T. A Brief History of the Internet. 2017. Available online: https://sciencenode.org/feature/a-brief-history-of-theinternet-.php (accessed on 9 July 2019).

10. Balmer, J.; Yen, D. The Internet of total corporate communications, quaternary corporate communications and the corporate marketing Internet revolution. J. Mark. Manag. 2016, 33, 131-144. [CrossRef]

11. Chung, S.; Lee, J.; Lee, H. Personal Factors, Internet Characteristics, and Environmental Factors Contributing to Adolescent Internet Addiction: A Public Health Perspective. 2019. Available online: https://www.mdpi.com/1660-4601/16/23/4635 (accessed on 1 July 2020).

12. BBC. How Does the Internetwork? 2019. Available online: https://www.bbc.com/bitesize/articles/z3tbgk7 (accessed on 10 July 2019).

13. Mitchell, B. DSL vs. Cable: Broadband Internet Speed Comparison. 2019. Available online: https://www.lifewire.com/dsl-vscable-broadband-internet-speed-comparison-817539 (accessed on 21 June 2019).

14. Albiges, L. Standard ADSL Broadband vs. Fibre Broadband. 2019. Available online: https://www.cable.co.uk/broadband/ guides / standard-vs-fibre/ (accessed on 29 June 2019).

15. Ofcom. Broadband Speeds Boost for UK Homes. 2019. Available online: https://www.ofcom.org.uk/about-ofcom/latest/ media/media-releases/2019/broadband-speeds-boost-for-uk-homes (accessed on 6 July 2019).

16. Middleton, C. Broadband Is the Key Infrastructure for the 21st Century. 2015. Available online: http:/ / theconversation.com/ broadband-is-the-key-infrastructure-for-the-21st-century-47946 (accessed on 2 July 2019). 
17. Highlands and Islands Enterprise. Full Speed Ahead for Tiree after Community Broadband Scotland Approves Funding Injection. 2019. Available online: http://news.hie.co.uk/all-news/full-speed-ahead-for-tiree-after-community-broadband-Scotlandapproves-funding-injection/ (accessed on 4 May 2019).

18. International Telecommunications Union. Measuring the Information Society Report 2018 Volume 1. 2018. Available online: https: //www.itu.int/en/ITU-D/Statistics/Documents/publications/misr2018/MISR-2018-Vol-1-E.pdf (accessed on 15 July 2019).

19. Philip, L.; Cottrill, C.; Farrington, J.; Williams, F.; Ashmore, F. The Digital Divide: Patterns, Policy and Scenarios for Connecting the 'Final Few' in Rural Communities across Great Britain. 2017. Available online: http://www.sciencedirect.com/science/ article/pii/S0743016716306799 (accessed on 4 May 2017).

20. Philip, L.; Williams, F. Remote-rural home-based businesses and digital inequalities: Understanding needs and expectations in a digitally underserved community. J. Rural. Stud. 2019, 68, 306-318. [CrossRef]

21. Gerli, P.; Whalley, J. Conference Paper: Fibre to the Countryside: A Comparison of Public and Community Initiatives in the UK. 2018. Available online: https:/ / www.econstor.eu/bitstream/10419/184941/1/Gerli-Whalley.pdf (accessed on 11 November 2019).

22. Van Deursen, A.; Van Dijk, J. The first-level digital divide shifts from inequalities in physical access to inequalities in material access. New Media Soc. 2018, 21, 354-375. [CrossRef]

23. Blankson, A. The Coming of The Second Digital Divide and What We Can Do About It. 2018. Available online: https:/ / www.forbes.com/sites/amyblankson/2018/11/06/the-coming-of-the-second-digital-divide-and-what-we-cando-about-it/\#6b16d8d42261 (accessed on 29 September 2019).

24. Dearing, A. Sustainable Innovation: Drivers and Barriers. Available online: https://www.oecd.org/innovation/inno/2105727.pdf (accessed on 11 October 2018).

25. Horberry, T.; Regan, M.; Stevens, A. Driver Acceptance of New Technology: Theory, Measurement and Optimisation; Routledge: London, UK, 2014; pp. 111-114.

26. Lima, E.; Hopkins, T.; Gurney, E.; Shortall, O.; Lovatt, F.; Davies, P.; Williamson, G.; Kaler, J. Drivers for Precision Livestock Technology Adoption: A Study of Factors Associated with the Adoption of Electronic Identification Technology by Commercial Sheep Farmers in England and Wales. 2018. Available online: https://journals.plos.org/plosone/article?id=10.1371/journal. pone.0190489 (accessed on 20 October 2018).

27. Bacchi, C.; Goodwin, S. Poststructural Policy Analysis; Palgrave Macmillan: New York, NY, USA, $2016 ;$ pp. 58-59.

28. Kraft, M.; Furlong, S. Public Policy: Politics, Analysis and Alternatives, 6th ed.; Sage: London, UK, 2018; pp. 118-119.

29. Weimer, D.; Vining, A. Policy Analysis: Concepts and Practice, 6th ed.; Routledge: New York, NY, USA, 2017 ; pp. 30-31.

30. Kraus, S.; Kailer, N.; Dorfer, J.; Jones, P. Open innovation in (young) SMEs. Int. J. Entrep. Innov. 2019, 21, 47-59. [CrossRef]

31. Loader, K. Supporting SMEs through Government Purchasing Activity. Int. J. Entrep. Innov. 2005, 6, 17-26. [CrossRef]

32. Nyarku, K.; Oduro, S. Effect of legal and regulatory framework on SMEs growth in the Accra Metropolis of Ghana. Int. J. Entrep. Innov. 2017, 19, 207-217. [CrossRef]

33. National Federation of Self Employed \& Small Businesses. UK Small Business Statistics: Business Population Estimates for the UK and Regions in 2020. 2021. Available online: https:/ / www.fsb.org.uk/uk-small-business-statistics.html (accessed on 9 June 2021).

34. Smith, A.; Galloway, L.; Jackman, L.; Danson, M.; Whittam, G. Poverty, social exclusion and enterprise policy: A study of UK policies' effectiveness over 40 years. Int. J. Entrep. Innov. 2019, 20, 107-118. [CrossRef]

35. Quinn, B.; McKitterick, L.; McAdam, R.; Dunn, A. Barriers to Micro Food Enterprise Engagement in Business Support Programmes. Int. J. Entrep. Innov. 2014, 15, 205-217. [CrossRef]

36. Primrose, D.; Fawcett, J. Evaluation of the Scottish Executive's “Broadband for Scotland" Intervention. 2007. Available online: https:/ / www2.gov.scot/resource/doc/212800/0056576.pdf (accessed on 9 July 2019).

37. Scottish Government. Official Report: Meeting of the Parliament 30 June 2011. 2011. Available online: https://archive2021. parliament.scot/parliamentarybusiness / report.aspx?r=6578\&mode=html (accessed on 30 October 2021).

38. Scottish Government. Reaching 100\%: Superfast Broadband for All. 2017. Available online: https://www.gov.scot/publications/ reaching-100-superfast-broadband/ (accessed on 3 July 2019).

39. Scottish Government. Defining Scotland by Rurality. 2019. Available online: https://www2.gov.scot/Topics/Statistics/About/ Methodology/UrbanRuralClassification (accessed on 1 July 2019).

40. Superfast Broadband Digital Scotland. The DSSB Programme. 2019. Available online: https://www.scotlandsuperfast.com/ (accessed on 1 July 2019).

41. Meade, N.; Islam, T. Forecasting in telecommunications and ICT-A review. Int. J. Forecast. 2015, 31, 1105-1126. [CrossRef]

42. Lavassani, K.; Movahedi, B.; Parry, G. Broadband Internet adoption challenge: An investigation of broadband utilisation in the United States. Transform. Gov. People Process Policy 2014, 8, 620-644. [CrossRef]

43. Li, R.; Chung, T.; Fiore, A. Factors affecting current users' attitude towards e-auctions in China: An extended TAM study. J. Retail. Consum. Serv. 2016, 34, 19-29. [CrossRef]

44. Hoti, E. The Technological Organisational Environmental Framework of IS Innovation Adaption in Small and Medium Enterprises. Evidence from Research over the last 10 years. Int. J. Bus. Manag. 2015, 3, 1-14. [CrossRef]

45. Boucher, B. The Bass Diffusion Model for Communication Technology Globally and the Economic Factors that Influence it. 2019. Available online: https:/ / scholar.sun.ac.za/bitstream/handle/10019.1/106166/boucher_bass_2019.pdf?sequence=2\&isAllowed= y (accessed on 3 July 2019). 
46. Koichu, B.; Keller, M. Implementation Enterprise through the Lens of a Theory of Diffusion of Innovations: A Case of Online Problem-Solving Forums. 2017. Available online: https:/ / hal.archives-ouvertes.fr/hal-01950521/ (accessed on 10 July 2019 ).

47. Gilani, S.A.M. Drivers and Barriers for Broadband Adoption and Broadband Use by Food and Drink Micro-Business OwnerManagers Based in Remote-Rural Scotland. 2021. Available online: https://www.gcu.ac.uk/library/onlineresources/theses/ (accessed on 10 November 2021).

48. Chesbrough, H.; Vanhaverbeke, W.; West, J. Open innovation. New Imp. Creat. Profit. Technol. 2006, 1, 1-11. Available online: https:/ / doc1.bibliothek.li/aas/FLMF016763.pdf (accessed on 23 December 2021).

49. Lee, S.M.; Hwang, T.; Choi, D. Open innovation in the public sector of leading countries. Manag. Decis. 2012, 50, 147-162. [CrossRef]

50. Cronin, P.; Ryan, F.; Coughlan, M. Undertaking a Literature Review: A Step-by-Step Approach. 2013. Available online: https:/ / www.magonlinelibrary.com/doi/abs/10.12968/bjon.2008.17.1.28059 (accessed on 29 July 2021).

51. Tookey, A.; Whalley, J.; Howick, S. Broadband diffusion in remote and rural Scotland. Telecommun. Policy 2006, 30 , 481-495. [CrossRef]

52. Efron, S.; Ravid, R. Writing the Literature Review: A Practical Guide; The Guilford Press: New York, NY, USA, 2019; pp. 1-2.

53. Gough, D.; Oliver, S.; Thomas, J. An Introduction to Systematic Reviews, 2nd ed.; Sage: New York, NY, USA, 2019 ; pp. 2-3.

54. Moher, D.; Liberati, A.; Tetzlaff, J.; Altman, D. Preferred Reporting Items for Systematic Reviews and Meta-Analyses: The PRISMA Statement. PLoS Med. 2009, 6, e1000097. [CrossRef]

55. Galvan, J. Writing Literature Reviews, 6th ed.; Routledge: London, UK, 2017; pp. 4-6.

56. The University of South Carolina. How to Conduct a Literature Review: Types of Literature Reviews. 2019. Available online: https:/ / guides.lib.ua.edu/c.php?g=39963\&p=253698 (accessed on 22 July 2019).

57. Clark, I. Bardach's Eightfold Path to More Effective Problem Solving. 2017. Available online: http://www.atlas101.ca/pm/ concepts/bardachs-eightfold-path-to-more-effective-problem-solving/ (accessed on 10 July 2019).

58. Erdman, J. An 8-Step Process to Making Well-Informed Decisions and Opinions. 2018. Available online: https://medium.com/ the-post-grad-survival-guide/an-8-step-process-to-making-well-informed-decisions-and-opinions-42d4d94d1476 (accessed on 11 July 2019).

59. Whalley, J.; Howick, S. Broadband in Rural and Remote Areas: The Impact of Scottish Policy Initiatives. 2008. Available online: https:/ / pureportal.strath.ac.uk/ files-asset/65077726/strathprints007457.pdf (accessed on 30 June 2019).

60. British Telecommunications. A History of Openreach. 2019. Available online: https://www.openreach.com/about-us/ourhistory (accessed on 2 July 2019).

61. Grabham, D. What Is BT Openreach? Everything you Need to Know. 2017. Available online: https://www.techradar.com/uk/ news / what-is-bt-openreach-everything-you-need-to-know (accessed on 1 July 2019).

62. Dutra, I.; Findlay, C.; McGregor, M.; McEwan, T. E-Procurement \& the SME: Challenges for Scotland. 2006. Available online: http:/ / researchrepository.napier.ac.uk/3703/ (accessed on 9 January 2015).

63. Broadband and Mobile. Available online: https://www.gov.scot/policies/digital/broadband-and-mobile/ (accessed on 30 October 2021).

64. European Commission. Lowlands and Uplands: Eligible Area under the Convergence Objective and the Regional Competitiveness and Employment Objective. 2018. Available online: https:/ / ec.europa.eu/regional_policy/archive/atlas2007/uk/ukm6_en.htm (accessed on 2 July 2019).

65. Scottish Government. A Digital Ambition for Scotland. 2010. Available online: https://www.webarchive.org.uk/wayback/ archive/20180517200920/http://www.gov.scot/Publications/2010/10/Digital/Digital-Ambition (accessed on 1 July 2019).

66. BBC. UK Homes to Get Faster Broadband by 2020. 2017. Available online: https://www.bbc.co.uk/news/business-42423047 (accessed on 29 June 2019).

67. Mercer-Myers, C. A History of UK Broadband Roll out: BT, Openreach and Other Major Milestones. 2018. Available online: https: //www.computerworlduk.com/galleries/infrastructure/history-of-uk-broadband-2000-now-3629899/ (accessed on 2 July 2019).

68. Hutton, G. Gigabit-Broadband in the UK: Government Targets and Policy. 2021. Available online: https://researchbriefings.files. parliament.uk/documents/CBP-8392/CBP-8392.pdf (accessed on 25 June 2021).

69. Scottish Government. Lowlands and Uplands Scotland: European Regional Development Fund 2007-2013: Operational Programme: Version 2-September 2009. 2010. Available online: https://www.webarchive.org.uk/wayback/archive/20171002 001613/http:/ / www.gov.scot/Publications/2010/05/25142835/0 (accessed on 3 July 2019).

70. Wilson, R.; Hopkins, J. The Changing Shape of Scotland's Digital Divide. Eur. Countrys. 2019, 11, 563-583. [CrossRef]

71. Sutherland, E. Broadband in Scotland: Broader, Faster, Poorer, Remoter. 2017. Available online: http://strathprints.strath.ac.uk/ 60284/ (accessed on 20 April 2017).

72. European Commission. Broadband Strategy and Policy. 2019. Available online: https://ec.europa.eu/digital-single-market/en/ broadband-strategy-policy (accessed on 7 July 2019).

73. European Commission. What Is an SME? 2019. Available online: https://ec.europa.eu/growth/SMEs/business-friendlyenvironment/sme-definition_en (accessed on 28 June 2019).

74. Docherty, C. Glasgow Economic Commission: Final Report. 2011. Available online: http:/ /glasgoweconomicleadership.com/ wp-content/uploads/document-3.pdf (accessed on 30 October 2021). 
75. Scottish Government. Scotland's Digital Future a Strategy for Scotland. 2011. Available online: https://www2.gov.scot/resource/ doc/981/0114237.pdf (accessed on 9 July 2019).

76. British Telecom. Preparing for Scotland's Digital Future. 2021. Available online: https://business.bt.com/content/dam/bt/ business/v2/PDF/Publicsector/Scotlands\%20digital\%20future.pdf (accessed on 20 June 2021).

77. Jackson, M. BT Pledge to "Significantly" Boost UK Rollout of Ultrafast FTTP Broadband. 2016. Available online: https: / / www.ispreview.co.uk/index.php/2016/03/bt-pledge-significantly-boost-rollout-ultrafast-fttp-broadband.html (accessed on 10 June 2019).

78. Budge, S. Digital Scotland Superfast Broadband Programme Celebrates Two-Year Anniversary. 2016. Available online: https: //www.scotlandstowns.org/digital_scotland_superfast_broadband_programme_celebrates_two_year_anniversary (accessed on 25 June 2019).

79. Orkney Islands Council and Highlands and Islands Enterprise. Get Connected in Orkney. 2019. Available online: http: //www.orkney.com/invest/connectivity (accessed on 30 April 2019).

80. Burgauer, A. Manifesto for Rural Scotland. 2017. Available online: https://www.scottishruralparliament.org.uk/manifesto/ (accessed on 30 April 2017).

81. Du Pre News. 700,000 Homes and Businesses in Scotland Get Superfast Internet. 2017. Available online: http:/ /www.dupre.co. uk/high-speed-internet/700000-homes-businesses-Scotland-get-superfast-internet/ (accessed on 2 May 2017).

82. British Telecommunications. Community Fibre Partnerships Partner with Openreach to Get Faster Broadband to Your Community. 2019. Available online: https://www.openreach.com/fibre-broadband/community-fibre-partnerships (accessed on 1 July 2019 ).

83. UK Government. Better Broadband Scheme Extended to 2019. 2018. Available online: https://www.gov.uk/government/news/ better-broadband-scheme-extended-to-2019 (accessed on 1 July 2019).

84. Jackson, M. Ofcom Set March 2020 Launch for 10 Mbps UK Broadband USO. 2019. Available online: https:/ / www.ispreview.co uk/index.php/2019/06/ofcom-set-march-2020-launch-for-10mbps-uk-broadband-uso.html (accessed on 2 July 2019).

85. Cave, M.; Feasey, R. Policy towards Competition in High-Speed Broadband in Europe. 2017. Available online: https://cerre.eu/ publications / policy-towards-competition-high-speed-broadband-europe/ (accessed on 30 October 2021).

86. European Network of Rural Development. Smart Villages. 2019. Available online: https://enrd.ec.europa.eu/enrd-thematicwork/smart-and-competitive-rural-areas/smart-villages_en (accessed on 5 July 2019).

87. McLaughlin, M. Dig-Your-Own Broadband in Scottish Wilderness Reaps Rewards. 2017. Available online: https://www.scotsman com/regions/inverness-highlands-islands/dig-your-own-broadband-in-scottish-wilderness-reaps-rewards-1-4613477 (accessed on 11 November 2017).

88. Scottish Government. Scotland's Digital Strategy: Evidence Discussion Paper. 2017. Available online: https://www.gov. scot/binaries/content/documents/govscot/publications / consultation-paper/2017/03/scotlands-digital-strategy-evidencediscussion-paper/documents/00515576-pdf/00515576-pdf/govscot\%3Adocum (accessed on 17 July 2019).

89. Jackson, M. New BT CEO Reports Ultrafast Broadband Cover of 3.2M UK Premises. 2019. Available online: https://www. ispreview.co.uk/index.php/2019/05/new-bt-ceo-reports-ultrafast-broadband-cover-of-3-2m-uk-premises.html (accessed on 25 June 2019).

90. Scottish Policy Foundation. A Brief History. 2020. Available online: https://www.scottishpolicyfoundation.org/devolved-powers (accessed on 3 November 2020).

91. Wakefield, J. BT Offers Universal Broadband in Place of Regulation. 2017. Available online: http://www.bbc.co.uk/news/ technology-40751449 (accessed on 14 August 2017).

92. Ogston, G. Villagers Dig in for Own Broadband Network. 2017. Available online: http://www.bbc.co.uk/news/uk-Scotlandtayside-central-39692030 (accessed on 20 April 2017).

93. Nisbet, D. Digital Scotland-Reaching 100\% Programme: Public Consultation Report. 2018. Available online: https://www.gov. scot/publications / digital-scotland-reaching-100-programme-public-consultation-report/ (accessed on 10 July 2019).

94. UK Government. Details of the Plan to Achieve a Transformation in Broadband in the UK. 2019. Available online: https: / / www.gov.uk/guidance/building-digital-uk (accessed on 3 July 2019).

95. Hutton, G.; Baker, C. Superfast Broadband in the UK. 2018. Available online: https://researchbriefings.files.parliament.uk/ documents/SN06643/SN06643.pdf (accessed on 5 July 2019).

96. BBC. Broadband Boost for Remotest Parts of UK. 2016. Available online: http://www.bbc.co.uk/news/technology-38397304 (accessed on 30 December 2016).

97. Jackson, M. BDUK Superfast Broadband Take-up Progress by UK Region-Q4 2018. 2019. Available online: https://www. ispreview.co.uk/index.php/2019/04/bduk-superfast-broadband-take-up-progress-by-uk-region-q4-2018.html (accessed on 30 June 2019).

98. BBC. Bid to Improve Rural Broadband Speeds. 2016. Available online: http://www.bbc.co.uk/news/uk-Scotland-38401244 (accessed on 30 December 2016).

99. Howdle, D. What Is Ultrafast Broadband? 2020. Available online: https://www.cable.co.uk/broadband/guides/ ultrafast-broadband/\#: \{\}:text=\%27Ultrafast $\% 27 \%$ 20broadband $\% 20$ is $\% 20$ a $\% 20$ connection,house $\% 20$ and $\% 20$ the $\% 20$ nearest $\%$ 20exchange (accessed on 24 May 2021).

100. Jackson, M. Openreach Name 67 UK Areas for Next FTTP Broadband Rollout. 2021. Available online: https://www.ispreview.co. uk/index.php/2020/09/openreach-confirm-67-uk-areas-for-next-fttp-broadband-rollout.html (accessed on 11 May 2021). 
101. Ofcom. Connected Nations 2019: Scotland Report. 2021. Available online: https://www.ofcom.org.uk/_data/assets/pdf_file/ 0028/186409/connected-nations-2019-scotland-report.pdf (accessed on 17 May 2021).

102. Allan, A. Chamber and Committees. 2019. Available online: https://www.parliament.scot/chamber-and-committees/writtenquestions-and-answers / question?ref=S5W-24512 (accessed on 20 June 2021).

103. Superfast Broadband. You Can Go Much Faster with Fibre. 2018. Available online: https://www.scotlandsuperfast.com/ (accessed on 15 November 2018).

104. UK Government. RGC Programme Key Information. 2019. Available online: https://www.gov.uk/government/publications/ rgc-programme-key-information (accessed on 10 May 2021).

105. My Society. R100 Superfast Broadband Programme. 2018. Available online: https://www.theyworkforyou.com/sp/?id=2018-0118.2.0 (accessed on 17 November 2018).

106. Baglow, B. UK Strips Scottish Government of Broadband Powers. 2017. Available online: https:/ / digit.fyi/scotlands-broadbandpowers-stripped/ (accessed on 30 September 2020).

107. Jackson, M. Scotland's R100 Broadband Contract Delayed until End of 2019. 2019. Available online: https:/ /www.ispreview.co. uk/index.php/2019/06/scotlands-r100-broadband-contract-delayed-until-end-of-2019.html (accessed on 1 July 2019).

108. Paun, A. The Paradox of Scottish Devolution. 2016. Available online: https://www.instituteforgovernment.org.uk/blog/ paradox-scottish-devolution?gclid=Cj0KCQiAhZT9BRDmARIsAN2E-J3GFRanSJ0cS6uIL487AjZvdfgpFQlncxBlyOIlbT5 knhjjQFmIBUUaAm45EALw_wcB (accessed on 30 October 2020).

109. Adcock, A.; Baker, C.; Downing, E.; Hutton, G. Roll-out of Broadband to Rural Communities in Scotland. 2017. Available online: https:/ / commonslibrary.parliament.uk/research-briefings/cdp-2017-0232/ (accessed on 30 September 2020).

110. Jackson, M. Scotland and UK Gov Told to STOP Squabbling over Broadband UPDATE. 2018. Available online: https:/ / www.ispreview. co.uk/index.php/2018/07/scotland-and-uk-gov-told-to-stop-squabbling-over-broadband.html (accessed on 6 October 2020).

111. Scottish Government. Businesses in Scotland-Key Facts. 2016. Available online: http://www.gov.scot/Topics/Statistics/ Browse/Business /Corporate/KeyFacts (accessed on 7 January 2017).

112. Dekkers, R.; Koukou, M.; Mitchell, S.; Sinclair, S. Engaging with open innovation: A Scottish perspective on its opportunities, challenges and risks. J. Innov. Econ. Manag. 2019, 28, 193-226. [CrossRef]

113. Scotland Can Do. Remote Rehabilitation Service for Isolated Areas (ROSIA). 2021. Available online: https://www.openinnovation. scot/find-a-challenge (accessed on 17 November 2021).

114. Scottish Enterprise. What We Do. 2021. Available online: https://www.scottish-enterprise.com/our-organisation/what-we-do (accessed on 30 October 2021)

115. Scottish Government. Scottish Enterprise Open Innovation Challenges for SMEs to Develop Future Technologies and Solutions. 2016. Available online: https://www.sdpscotland.co.uk/news/news/scottish-enterprise-open-innovation-challenges-smesdevelop-future-technologies-solutions / (accessed on 11 November 2021).

116. Scottish Government. About Us. 2021. Available online: https:/ / findbusinesssupport.gov.scot/about-us (accessed on 30 October 2021).

117. Kayne, J. State Entrepreneurship Policies and Programs; Kauffman Center for Entrepreneurial Leadership at the Ewing Marion Kauffman Foundation: Kansas City, MO, USA, 1999; pp. 1-36. Available online: https://papers.ssrn.com/sol3/papers.cfm? abstract_id=1260444 (accessed on 23 December 2021).

118. Yoshida, A.D.; Gil-Herrera, R.J. Liberalization and Nationalization in South America: A Comparative Analysis of Economics Impact Through Telecommunications and Electricity Sectors. Int. J. Bus. Econ. Res. 2020, 9, 211. [CrossRef]

119. Fitsanakis, J. The Government and Telecommunications: A Complex History. In Redesigning Wiretapping; Springer: Berlin/Heidelberg, Germany, 2020; pp. 27-50.

120. Conrad, C.A. Market Failure. In Political Economy; Springer Gabler: Wiesbaden, Germany, 2020; pp. 175-225.

121. Goerres, A.; Karlsen, R.; Kumlin, S. What makes people worry about the welfare state? A three-country experiment. Br. J. Political Sci. 2020, 50, 1519-1537. [CrossRef]

122. Schmidt, M.G. Partisan Theory and the Welfare State. In The Oxford Handbook of the Welfare State; Oxford University Press: Oxford, UK, 2021; Volume 298, pp. 600-637.

123. Dukelow, F. Debt, austerity capitalism and the welfare state. In Handbook on Society and Social Policy; Edward Elgar Publishing: Cheltenham, UK, 2020.

124. Bardhan, P. Clientelism and Governance (No. wp-2021-116); World Institute for Development Economic Research (UNU-WIDER): Helsinki, Finland, 2021.

125. Rothstein, B. Corruption, Happiness, Social Trust and the Welfare State: A Causal Mechanisms Approach; QoG working paper series; University of Gothenburg: Gothenburg, Sweden, 2010; Volume 9, pp. 1-24.

126. Dhawan, N. The Unbearable Slowness of Change: Protest Politics and the Erotics of Resistance. The Philosophical Salon. 2015. Available online: http: / thephilosophicalsalon.com/the-unbearable-slowness-of-change-protest-politics-and-the-erotics-ofresistance (accessed on 23 December 2021).

127. Gereffi, G.; Humphrey, J.; Sturgeon, T. The governance of global value chains. Rev. Int. Political Econ. 2005, 12, 78-104. [CrossRef]

128. Mansfield, E. Long waves and technological innovation. Am. Econ. Rev. 1983, 73, 141-145.

129. Bergfors, M.E.; Larsson, A. Product and process innovation in process industry: A new perspective on development. J. Strategy Manag. 2009, 2, 261-276. [CrossRef]

130. Vanhaverbeke, W.; Cloodt, M. Open innovation in value networks. Open Innov. Res. A New Paradig. 2006, 1, $258-281$. 
131. Cheng, C.C.; Huizingh, E.K. When is open innovation beneficial? The role of strategic orientation. J. Prod. Innov. Manag. 2014, 31, 1235-1253. [CrossRef]

132. Available online: https://www.openinnovation.scot/support-and-funding (accessed on 23 December 2021).

133. Open Innovation Marketplace. Available online: https:/ findbusinesssupport.gov.scot/service/consultancy-and-advice/openinnovation-marketplace (accessed on 23 December 2021).

134. Chesbrough, H.W. Open Innovation: The New Imperative for Creating and Profiting from Technology; Harvard Business Press: Boston, MA, USA, 2003.

135. Castaldo, S.; Perrini, F.; Misani, N.; Tencati, A. The missing link between corporate social responsibility and consumer trust: The case of fair trade products. J. Bus. Ethics 2009, 84, 1-15. [CrossRef]

136. Perkmann, M.; Walsh, K. University-industry relationships and open innovation: Towards a research agenda. Int. J. Manag. Rev. 2007, 9, 259-280. [CrossRef]

137. Etzkowitz, H.; Leydesdorff, L. Introduction to special issue on science policy dimensions of the Triple Helix of university-industrygovernment relations. Sci. Public Policy 1997, 24, 2-5.

138. Von Hippel, E. Open source software projects as user innovation networks. Perspect. Free. Open-Source Softw. 2005, 267-278. Available online: https://wiki.cs.pdx.edu/cs510osse-fall2008/vonhippel.pdf (accessed on 23 December 2021).

139. Powell, W.W.; Grodal, S. Networks of innovators. In The Oxford Handbook of Innovation; Oxford University Press: Oxford, UK, 2005.

140. Pyka, A.; Scharnhorst, A. Introduction: Network perspectives on innovations: Innovative networks-network innovation. In Innovation Networks; Springer: Berlin/Heidelberg, Germany, 2009; pp. 1-16.

141. Dahlander, L.; Gann, D.M. How open is innovation? Res. Policy 2010, 39, 699-709. [CrossRef]

142. Kovacs, A.; Van Looy, B.; Cassiman, B. Exploring the scope of open innovation: A bibliometric review of a decade of research. Scientometrics 2015, 104, 951-983. [CrossRef]

143. Chesbrough, H.; Vanhaverbeke, W.; West, J. (Eds.) New Frontiers in Open Innovation; Oxford University Press: Oxford, UK, 2014.

144. Spithoven, A.; Teirlinck, P.; Frantzen, D. Managing Open Innovation: Connecting the Firm to External Knowledge; Edward Elgar Publishing: Cheltenham, UK, 2012.

145. Tidd, J. Conjoint innovation: Building a bridge between innovation and entrepreneurship. Int. J. Innov. Manag. $2014,18,1450001$. [CrossRef]

146. Fry, C.; Mention, A.L.; Temel, S.; Torkkeli, M. Exploring time lag effects of open innovation practices on performance during economic turmoil. Int. J. Bus. Innov. Res. 2016, 10, 184-208. [CrossRef]

147. Vanhaverbeke, W.; Roijakkers, N. Enriching open innovation theory and practice by strengthening the relationship with strategic thinking. In Strategy and Communication for Innovation; Springer: Berlin/Heidelberg, Germany, 2013; pp. 15-25.

148. Appleyard, M.M.; Chesbrough, H.W. The dynamics of open strategy: From adoption to reversion. Long Range Plan. $2017,50,310-321$. [CrossRef]

149. Dagnino, G.B.; Levanti, G.; Mina, A.; Picone, P.M. Interorganizational network and innovation: A bibliometric study and proposed research agenda. J. Bus. Ind. Mark. 2015, 30, 354-377. [CrossRef]

150. Phelps, C.; Heidl, R.; Wadhwa, A. Knowledge, networks, and knowledge networks: A review and research agenda. J. Manag. 2012, 38, 1115-1166. [CrossRef]

151. Provan, K.G.; Fish, A.; Sydow, J. Interorganizational networks at the network level: A review of the empirical literature on whole networks. J. Manag. 2007, 33, 479-516. [CrossRef]

152. Greco, M.; Locatelli, G.; Lisi, S. Open innovation in the power \& energy sector: Bringing together government policies, companies' interests, and academic essence. Energy Policy 2017, 104, 316-324.

153. Solesvik, M.; Gulbrandsen, M. Partner selection for open innovation. Technol. Innov. Manag. Rev. 2013, 3, 6-11. [CrossRef]

154. Piga, G. A fighting chance against corruption in public procurement. Int. Handb. Econ. Corrupt. 2011, 2, 141-181.

155. Vargas-Hernández, J.G. The multiple faces of corruption: Typology, forms and levels. In Organizational Immunity to Corruption: Building Theoretical and Research Foundations; Information Age Publishing: Charlotte, NC, USA, 2009; pp. 111-117.

156. Kaslow, F.W. Handbook of Family Business and Family Business Consultation: A Global Perspective; Routledge: London, UK, 2006.

157. Houston, D.; Varna, G.; Docherty, I. The political economy of and practical policies for inclusive growth-A case study of Scotland. Camb. J. Reg. Econ. Soc. 2021, 14, 197-215. [CrossRef]

158. Theodoropoulou, E.; Mesogiti, I.; Setaki, F.; Filis, K.; Lyberopoulos, G.; Mesodiakaki, A.; Gatzianas, M.; Vagionas, C.; Kalfas, G.; Agus, M.; et al. Top Challenges in 5G Densification. In Proceedings of the IFIP International Conference on Artificial Intelligence Applications and Innovations, Crete, Greece, 25-27 June 2021; pp. 118-127.

159. Jugend, D.; Fiorini, P.D.C.; Armellini, F.; Ferrari, A.G. Public support for innovation: A systematic review of the literature and implications for open innovation. Technol. Forecast. Soc. Change 2020, 156, 119985. [CrossRef]

160. Sabatino, G. The 'Golden Power' on Foreign Investments in EU Law in the Light of Covid Crisis. Eur. Co. Law 2021, 18, 189-195.

161. Raza, A.; Azam, M.; Tariq, M.; Sadiqa, B.A. An Empirical data investigation of the Greenfield investment: Welfare nexus from low-income countries. Int. J. Innov. Creat. Change 2021, 15, 820-835.

162. Perić, A. Brownfield Regeneration vs. Greenfield Investments-Case Study Ecka Industrial Zone in Zrenjanin, Serbia. Tech. Technol. Educ. Manag. 2011, 6, 541-551.

163. Mariotti, S.; Marzano, R. Varieties of capitalism and the internationalization of state-owned enterprises. J. Int. Bus. Stud. 2019, 50, 669-691. [CrossRef] 